\title{
The Ten Views of West Lake
}

\author{
Xiaolin Duan
}

In 1924, Leifeng Pagoda 雷鋒塔, which had stood for over a thousand years beside West Lake outside Hangzhou, suddenly collapsed. This news, which one might expect to be regarded as quite insignificant in such a politically unstable era, drew the attention not only of local people but also of the elite from all over the country. Literati found this incident to be a perfect opportunity to lament historical change and to argue in favor of having the tower rebuilt in order to keep the set of the Ten Views of West Lake 西湖十景 intact. The wellknown writer Lu Xun 魯迅 (1881-1936), however, used the incident to criticize traditional Chinese culture. He wrote, in his characteristically satirical tone,

Many of us in China ... have a sort of "ten views syndrome" or at least an "eight views syndrome," which reached epidemic proportions in the Qing dynasty, I should say. Look through any county annals, and you will find the district has ten sights, if not eight, such as "Moonlight on a Distant Village," "Quiet Monastery and Clear Bell," "Ancient Pool and Crystal Water."

What bothered Lu Xun was the extremely formulaic practice of assigning eight or ten four-character poetic phrases to epitomize the best local scenic sites. Long before Lu Xun, the Qing Dynasty literatus Zha Qichang 査其昌 (1713-1761) already had noted that local people routinely designated the requisite number of stereotyped titles. Commenting on the excessive use of eight or ten views, Zha complained, "as for the ten scenic views or eight scenic views, it is common to find them even in the gazetteers of remote areas. This is really a bad habit." 2

Though Zha Qichang and Lu Xun were correct that most of the "ten views" produced in late imperial times were clichéd, the Southern Song Ten Views of West Lake - probably the source of this "ten views syndrome" - for a long time had usefully served as a creative discourse that helped shape how people inter-

1 See Lu's "More Thoughts on the Collapse of Leifeng Pagoda" in Lu et al., Selected Works of Lu Hsun, 96.

2 (Qianlong) Haining xianzhi 3.422. 
acted with the natural landscape. The place titles associated with West Lake defined the spots that drew visitors' eyes, and influenced how these viewers interpreted what they saw. Unlike most of the titles that Lu Xun criticized, the Ten Views of West Lake drew extensively from the actual local scenery. This place-energized visual culture was intricately interconnected with social activities and cultural norms. On the one hand, it was rooted in, and in turn enhanced, local pride. And more broadly, it allowed any visitor to feel more familiar within the landscape. By investigating how the Ten Views of West Lake was envisioned, presented, and circulated during the Song, this chapter explores how visual and material cultures in this case were closely tied to both cultural geography and urban life.

While the tradition of sightseeing around West Lake dates back to the Tang Dynasty, Song visitors undoubtedly were the ones who initiated the process of systematically selecting its iconic spots. When exposed to a new environment, sightseers desire focal points to help them assimilate, and they tend to assign symbolic meanings to these focal locations. Their habits are embedded in culture, in "cultural styles, circulating images and texts of this and other places." This culturally influenced way of viewing surrounding nature helped visitors to connect with the landscape. Yi-fu Tuan labels this affective bond between people and place topophilia. ${ }^{4}$ Once the Ten Views of West Lake were enriched through art and literature, they became a perfect checklist for sightseers who wished to take in what West Lake had to offer. Paintings of the lake also evoked a sense of being there for people who were physically unable to visit. This form of enjoyment was traditionally called "travel while lying at ease" (臥游 woyou), a term first used by the early landscape painter Zong Bing 宗炳 (375-443). ${ }^{5}$

Place and time both offer constructive points of departure in studies of Chinese visual and material cultures. As Ronald Egan remarked, depicting the natural landscape involves a complicated process of conceptualizing and abstracting the natural elements. ${ }^{6}$ Specific places can serve as anchors for organizing cultural memories; they help people to construct their personal identities, and facilitate the joining of meaningful words and images. ${ }^{7}$ Eugene Wang, in his study of Leifeng Pagoda, approaches it as both a signpost and a literary topic: "In reality, a site is echoed in collective memory by its capacity to

3 Urry and Jonas, The Tourist Gaze 3.o, 17.

4 Tuan, Topophilia, 4.

5 Hua shanshui $x u$, 583-584.

6 Egan, "Nature and Higher Ideals," 303.

7 Clunas, Elegant Debts, 93; L. Liu, "Collecting the Here and Now," 57-69. 
inspire writings on it and the topical thinking it provokes." ${ }^{8}$ The meaning of places was frequently tied to the circulation and continuing interpretation of textual records. Past scholarship on the Eight Views of Xiao and Xiang 瀟湘八 景9 (a precursor of the Ten Views of the West Lake) demonstrates that interconnections between textual and visual records contributed to the wide circulation of specific sets of views, or visualizations, of nature. ${ }^{10}$

The Ten Views are specific to certain places but also evoke specific seasons or even times of day. Time functions as an important coordinate in one's memory. Watching the sunset, appreciating the reflection of the moon on the water, and enjoying the snowy scenery are experiences people could acquire in many other places. By connecting visual sites with more universal emotional attachments to nature, the Ten Views encourage spectators to recall and reflect upon their past experiences while contemplating the specific places around West Lake.

Such deliberate utilization of place and time should be kept in mind when analyzing the creation of the Ten Views in the Song period. Gazing at the sites, representing them in words or pictures, and circulating these images created a way of seeing and thinking about natural scenery that could be both personal and communal. In this chapter, the Ten Views are examined in contemporary manifestations of visual and material culture-poetry, maps, and paintings (particularly details of a special ten-leaf album of the Ten Views) - to show how their titles and intended meanings were constructed to evoke simultaneously a place, an artistic motif, and a culturally-laden naming convention. ${ }^{11}$

$8 \quad$ Wang, "Tope and Topos," 489.

9 The earliest extant pictorial example of the Eight Views is by the Northern Song literatus Song Di 宋迪 (jinshi during 1023-1032). The titles of the Eight Views are: “Wild Geese Descending to Sandbar 平沙落雁, “Returning Sail off Distant Shore 遠浦歸航, “Mountain Market, Clear with Rising Mist 山市晴嵐,” “River and Sky in Evening Snow 江天暮 雪, " “Autumn Moon over Lake Dongting 洞庭秋月, " “Night Rain on Xiao and Xiang 瀟湘 夜雨," “Evening Bell from Mist-shrouded Temple 煙寺晚鐘," and “Fishing Village in Evening Glow 漁村夕照." See Mengxi bitan 9.549. The translations of the eight titles are from Murck, "Eight Views of the Hsiao and Hsiang Rivers," 216. Also see Barnhart, "Shining Rivers"; I, "Landscape Like a Picture' and 'Landscape in the Picture', 33-70; "Song Yuan ti 'Xiaoxiang' shanshui huashi," 33-70; Lee, Exquisite Moments; Empresses, Art, and Agency, 171-79; Miyazaki, "Saiko wo meguru kaiga," 203; and Shi, Yidong de taohua yuan, 23-25. Shi, Yidong de taohua yuan; Murck, "Eight Views of the Hsiao and Hsiang." 


\section{The Origins of the Ten Views}

The earliest extant record of the Ten Views of West Lake is found in Zhu Mu's 祝穆 (?-1255) geographical work, Fangyu shenglan 方輿勝覽. He wrote:

People who were fond of things used to name [the scenery] using ten titles: Autumn Moon above the Placid Lake, Spring Dawn at Su Dike, Remnant Snow on Broken Bridge, Sunset on Leifeng Pagoda, Evening Bell from Nanping Hill, Lotus Breeze at Qu Winery, Watching Fish at Flower Cove, Listening to the Orioles by the Willow Ripples, Three Stupas and the Reflecting Moon, and Twin Peaks Piercing the Clouds.

\section{好事者嘗命十題, 有曰: 平湖秋月, 蘇堤春曉, 斷橋殘雪, 雷峯落 照, 南㞔晚鐘, 曲院風荷, 花港觀魚, 桝浪聞鶯, 三潭印月, 兩峯挿 雲。12}

The earliest extant paintings and poems on this topic are also dated to the 1250 s and 126os, suggesting that this was the period in which the Ten Views were invented. The Ten Views were meant to convey the essence of the West Lake experience through a set of sights and associated activities correlated with specific times of day and seasons (see Table 4.1 below).

Earlier researchers have long drawn attention to the practice of naming eight or ten sites with four-character poetic titles, and have pointed to connections between the Ten Views and the earlier convention of the Eight Views. However, the Ten Views differ from the Eight Views in several respects-above all, in their emphasis on specific locations and the inclusion of more human activities. While the Eight Views could be applied to many natural places in southern China during the Song period, eight of the Ten Views at West Lake include a specific place or structure. ${ }^{13}$ What might seem a minor elaboration of adding specific locales to the Eight Views in actuality had major consequences as it changed how people saw nature.

The Ten Views would not have become nearly as famous had it not been for the Jurchen conquest of north China and the Song relocation of the capital south to Hangzhou. Located at the south end of the Grand Canal and on the southeast coast, Hangzhou benefitted from both domestic waterway

$12 \quad$ Fangyu shenglan 1.6b-7a. The translation is from Lee, Exquisite Moments, 32.

13 Concerning the Eight Views, during the later Yuan Dynasty literati connected the eight views with actual locations in the Hunan area, and made the practice of assigning poetic names to certain scenic places fashionable. See Murck, Poetry and Painting in Song China, 260 . 
Title (numbered Location/

Construction Season Time Weather Plant Activity as on Figure 4.1) architecture date

\begin{tabular}{|c|c|c|c|c|c|c|c|}
\hline $\begin{array}{l}\text { 1. Autumn Moon } \\
\text { above the Placid } \\
\text { Lake 平湖秋月 }\end{array}$ & $\begin{array}{l}\text { Temple of the } \\
\text { Dragon King }\end{array}$ & $\begin{array}{l}\text { Song Dynasty } \\
(960-1276)\end{array}$ & Autumn & Night & Clear & & Watch \\
\hline $\begin{array}{l}\text { 2. Spring Dawn } \\
\text { at Su Dike } \\
\text { 蘇堤春曉 }\end{array}$ & Su Dike & $\begin{array}{l}\text { Northern Song } \\
(1089)\end{array}$ & Spring & Dawn & & & $\begin{array}{l}\text { Watch } \\
\text { and feel }\end{array}$ \\
\hline $\begin{array}{l}\text { 3. Remnant Snow } \\
\text { on Broken Bridge } \\
\text { 斷橋殘雪 }\end{array}$ & Bai Dike & $\begin{array}{l}\text { Before the } \\
\text { Tang Dynasty } \\
(618-907)\end{array}$ & Winter & & $\begin{array}{l}\text { After } \\
\text { snow }\end{array}$ & & $\begin{array}{l}\text { Watch } \\
\text { from } \\
\text { distance }\end{array}$ \\
\hline $\begin{array}{l}\text { 4. Sunset on } \\
\text { Leifeng Pagoda } \\
\text { 雷峰夕照 }\end{array}$ & $\begin{array}{l}\text { Leifeng } \\
\text { Pagoda }\end{array}$ & 975 & & Dusk & Clear & & Watch \\
\hline $\begin{array}{l}\text { 5. Evening Bell } \\
\text { from Nanping } \\
\text { Hill 南屏晚鐘 }\end{array}$ & $\begin{array}{l}\text { Jingci } \\
\text { Monastery } \\
\text { 淨慈寺 }\end{array}$ & 954 & & Dusk & & & Listen \\
\hline $\begin{array}{l}\text { 6. Lotus Breeze } \\
\text { at Qu Winery } \\
\text { 麴院風荷 }\end{array}$ & $\begin{array}{l}\text { Qu Garden/ } \\
\text { Winery }\end{array}$ & $\begin{array}{l}\text { Southern Song } \\
(1127-1276)\end{array}$ & Summer & & Breeze & Lotus & $\begin{array}{l}\text { Watch, } \\
\text { smell and } \\
\text { sense }\end{array}$ \\
\hline $\begin{array}{l}\text { 7. Watching Fish } \\
\text { at Flower Cove } \\
\text { 花港觀魚 }\end{array}$ & $\begin{array}{l}\text { At the foot of } \\
\text { Hua Family } \\
\text { Mountain }\end{array}$ & $\begin{array}{l}\text { Southern Song } \\
(1127-1276)\end{array}$ & & & Clear & Flower & $\begin{array}{l}\text { Fish } \\
\text { viewing }\end{array}$ \\
\hline $\begin{array}{l}\text { 8. Listening to } \\
\text { the Orioles by the } \\
\text { Willow Ripples } \\
\text { 柳浪聞鶯 }\end{array}$ & $\begin{array}{l}\text { Assembling } \\
\text { Scenery } \\
\text { Garden } \\
\text { (jujingyuan) }\end{array}$ & $\begin{array}{l}\text { Xiaozong } \\
\text { Reign (1127- } \\
1194)\end{array}$ & Spring & & Breeze & Willow & $\begin{array}{l}\text { Listen, } \\
\text { watch }\end{array}$ \\
\hline $\begin{array}{l}\text { 9. Three Stupas } \\
\text { and the Reflected } \\
\text { Moon } \\
\text { 三潭印月 }\end{array}$ & $\begin{array}{l}\text { Three } \\
\text { pagodas in } \\
\text { the heart of } \\
\text { the lake }\end{array}$ & $\begin{array}{l}\text { Built by Su Shi, } \\
\text { Northern Song } \\
\text { (around 1089) }\end{array}$ & & Night & Clear & & Watch \\
\hline $\begin{array}{l}\text { 10. Twin Peaks } \\
\text { Piercing the } \\
\text { Clouds } \\
\text { 兩峰插雲 }\end{array}$ & $\begin{array}{l}\text { Among the } \\
\text { mountains } \\
\text { west of the } \\
\text { lake. }\end{array}$ & $\begin{array}{l}\text { Tang Dynasty } \\
(618-907)\end{array}$ & $\begin{array}{l}\text { Spring } \\
\text { or } \\
\text { autumn }\end{array}$ & & Misty & & Watch \\
\hline
\end{tabular}


transportation and international maritime trade. Its population soon grew to an estimated one million people, making the city nearly four times as densely populated as Chang'an during the Tang Dynasty. ${ }^{14}$ Tuan said in his discussion of topophilia, "once society had reached a certain level of artifice and complexity, people would begin to take note, and appreciate, the relative simplicities of nature."15 Early in the period of the new capital, the imperial family and scholar-officials were the main sightseers at West Lake. But gradually, Hangzhou's commoners joined them, especially during festivals. ${ }^{16}$ In further explanation of this widening of interest, Cahill suggested that the hustle and bustle of city life there aroused a deep feeling of nostalgia due to both the loss of the north and the "closeness to nature that has characterized China's idealized past." 17

Attention to the lake also seems to have fit into a shift in elite interests. The Southern Song is widely seen as a period when the Chinese elites turned their attention away from the central government and its needs, shifting instead toward their home communities which they wrote about with evident pride. ${ }^{18}$ Local gentry sought to mitigate a feeling of political instability by faithfully and enthusiastically recording specific places. With their knowledge of the Northern Song's demise, the elite were highly conscious of the fact that dynasties have limited lives. ${ }^{19}$ But unlike dynasties which fall, local places have natural and cultural histories of their own, as well as geographical permanence. This perception could be reassuring in an age when the Song was threatened by the alien Jin and Yuan Dynasties. ${ }^{20}$

\section{The Ten Views in Poetry}

Naming scenic places with poetic titles was an enduring literati tradition. The ten titles at West Lake clearly reflect the influence of site names used in Tang

14 Gernet, Daily Life in China, 18.

15 Tuan, Topophilia, 103.

16 For records of how both commoners and elites enjoyed the lake scenery, see Wulin jiushi, 3.351.

17 Cahill, "The Imperial Painting Academy," 186.

18 Local pride in the Southern Song period is a subject that has been widely discussed in recent scholarship. Hymes has argued that during that time, the elite focused more on local affairs than on the central government. See Hymes, "Marriage, Descent Groups, and the Localist Strategy." Peter Bol also argued that the rise of local history was partly due to this transition. See Bol, "The Rise of Local History."

19 Bol, "The Rise of Local History," 61.

20 On the literati's sense of insecurity, see T.C. J. Liu, China Turning Inward, 147. 
and Northern Song gardens. In his study of the development of naming locations in Northern Song gardens, Robert Harrist argued that while the site names in Tang gardens were usually "simple references to the locations, surrounding scenery, or function of a site," the Northern Song garden owners "devoted far more attention to the moods and feelings, the literary, historical, and biographical associations that the named sites evoked."21 In the Tang period, Wang Wei's poems preserved the site names of his beloved Wangchuan Villa, including Southern Hillock, Willow Ripples, and Northern Hillock. These titles are reminiscent of the first two characters in the titles of the Ten Views, such as "Qu Winery," “Flower Coves," and "Double Peaks." Northern Song site names, such as Reading Hall, Fishing Hut, Pavilion for Playing with Water, and Pavilion for Watering Flowers in Sima Guang's 司馬光 (1019-1086) Garden of Solitary Enjoyment, remind one of "Watching Fish" and "Listening to Orioles" in the Ten Views at West Lake. By the Southern Song Dynasty, the two naming traditions, which emphasize natural scenery and human activity respectively, had been fused.

At least four collections of ten poems on the Ten Views of West Lake survive from the Southern Song Dynasty, written by Zhang Ju 張矩 (fl. 1253-1258), Wang Wei 王洧 (ac. around 1256), Zhou Mi 周密 (1232-1298), and Chen Yunping 陳允 平 (fl. 1275). ${ }^{22}$ Read as a whole, they reflect the vibrant poetry writing activities that were popular at West Lake during that period. Hangzhou literati were known for forming poetry clubs, in which they played poem-rhyming games during boating parties. Sometimes they collected their poems and published them. The Ten Views likely served as an apt choice for poetry competitions on many occasions.

Many poems could be read as miniature trip diaries that indicated where and how the sightseers had spent their time. For example, all of the poems about "Three Stupas and the Reflecting Moon" indicate that the scene was viewed from a lake boat. Interestingly, all four poets depicted a similar scene for "Spring Dawn at Su Dike." The sightseers enjoyed themselves around the lake all night; in the early morning, the courtesans, just awakened, had not yet

$21 \quad$ Harrist, "Site Names and their Meaning," 207.

22 For Wang Wei's poem, see Xihu youlan zhiyu 10.153. For Zhang Ju's poem: Yuxuan lidai shiyu 64.23-26. Zhou Mi's poems are from Juemiao hao cijian, 7.11-12. Chen's poems can be seen in Rihu yuchang, 80.663. Chen Qi 陳起 (fl. 13th century) was a well-known publisher who published an anthology for the River and Lake Poetry Club. See Pinzhou yudi pu 1.16a; F. Liu, Shengshi fanhua, 168. The preface to Zhou Mi's poems indicates that he had read Zhang Ju's poems and wanted to write his own versions to compete with them. Chen's preface indicates that Zhou also invited Chen to write, using this group of titles and rhymes. 
put on their make-up, while those who were eager to meet the girls had already arrived on horseback. Zhou Mi, for instance, wrote:

[At] Eastern Garden,

the night excursion just came to an end...

Quickly refresh their make-up, those who stayed on all night,

And mount a horse in a rush.

All because people who desire to seek beauty get up early.

Beside the dike, boats have been rushing for a while. ${ }^{23}$

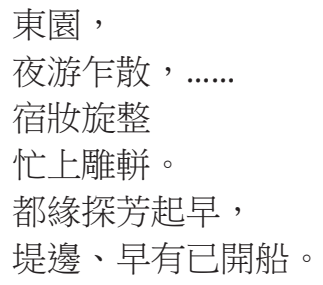

東園,

夜游乍散，......

宿妝旋整

忙上雕軿。

堤邊、早有已開船。

It is unclear why all of the poems shared this theme, the later poets may have copied the earlier themes intentionally, perhaps to combine respect for past masters with a claim of their own knowledge of that literary past and specific place. This trend also implies a common understanding of these lake excursions, which could last from late night to very early morning.

The Ten View poems also remind one of the verse-like structures of the Eight Views. ${ }^{24}$ Three of the four sets of West Lake poems changed the sequence of the ten titles, as they had been recorded by either Zhu Mu or Wu Zimu 吳自 牧 (fl. ca. 1270-1274). The reason for rearranging the ten titles seems to have been to seek better pairing possibilities (see Table 4.2).

Comparisons between poems about the Eight Views and the Ten Views reveal a striking difference. While the Eight Views conveyed the sentiments of someone in exile (such as "Night Rain on XiaoXiang"), poems about the Ten Views usually depicted flourishing sightseeing activities, even when the poems focused on the topic of the sunset, which was usually thought to arouse sorrowful feelings. ${ }^{25}$ For example, in the poem on "Sunset on Leifeng Pagoda," while the first half of the song lyric depicts the scenery before sunset, the second half starts from the moment of sunset:

23 Juemiao hao ci jian 7.10b. The scenery depicted by the Southern Song literati was presented in a set of woodblock prints in a late Ming book, which introduced the scene "Spring Dawn at Su Dike." This publication represents a further development of the coincidence of poems and paintings on the Ten Views. See Xinjuan hainei qiguan 3.407. For more on the Ming Dynasty print, see Duan, "A Comparative Study of Two Series," 224-49.

24 Murck argued that the Eight Views of the Xiao and Xiang Rivers imitated the structure of regulated verse. See Murck, "Eight Views of the Hsiao and Hsiang Rivers," 219-20.

25 For more discussion on the sentiment of exile expressed in the Eight Views, see Murck, Poetry and Painting in Song China. 
TABLE $4.2 \quad$ Poetic Structure of "Ten Views of West Lake"

\begin{tabular}{lll}
\hline Location+Season+Time & Spring Dawn at Su Dike & $\begin{array}{l}\text { Autumn Moon above the } \\
\text { Placid Lake }\end{array}$
\end{tabular}
Location+Lingering Beauty Sunset on Leifeng Pagoda Remnant Snow on Broken Bridge $\begin{array}{ll}\text { Location+Water Related Lotus Breeze at Qu Winery } & \text { Watching Fish at Flower } \\ \text { Scenery } & \text { Cove }\end{array}$

Sounds $\begin{array}{ll}\text { Listening to the Orioles by } & \text { Evening Bell from } \\ \text { the Willow Ripples } & \text { Nanping Hill }\end{array}$

The Numbers and Verbs are Twin Peaks Piercing the Perfect Matches Clouds Three Stupas and the Reflecting Moon

At the suburb, [tourists] are not yet bored with pleasure. Gloomy clouds crowd together, blinding the sorrow.

Stop singing and dancing.

The misty flowers and willows with dew are all left for the orioles.

Several gates, already locked,

Decorated carts and horses compete to enter the gate.

Silver candles light the flower [fire] to warm the night,

Forbidden streets with diluted moon around dusk.

\section{郊坸。未厭遊情。 雲暮合、謾消凝。 想罷歌停舞, 煙花露柳 都付棲䉆。}

重闣。已催鳳錀
正鈿車繡勒入爭門。
銀燭擎花夜暖,
禁街淡月黃昏。26

Although this part of the poem focuses on the ending phase of an excursion, that event is not overwhelmed by sentiment. Rather, the poet adds to the joyful picture of sightseeing by emphasizing the continuing pleasure, decorated carts, and silver candles.

It was not uncommon for scholar officials writing about West Lake to sing the praises of the central government. After being uprooted for several years due to the political turmoil after 1127, both the imperial court and many officials had a strong desire to settle down. They injected their yearning for a new home into their writings about West Lake, and also praised the government

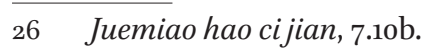


that would make that possible. This praise was certainly welcomed by the new court of Emperor Gaozong (r. 1127-1162), whose members saw their legitimacy confirmed by the prosperity they had helped to generate. Zhu Dunru 朱敦儒 (1081-1159), who in 1135 served as judicial commissioner of Zhedong circuit, praised the court by referencing West Lake:

Nowadays the true environment around West Lake is the revitalization of sagely rulership.

One only needs to listen to the music and watch the dancing; the fragrances linger, and deep cups are filled with wine. Celebrating the good years and the peace that pervades the country is the best part.

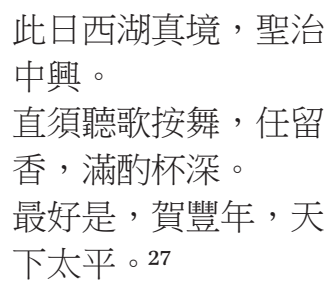

This poem starts with praise for the restoration and ends by declaring an age of great peace. The word zhongxing (restoration) conveys the desire to recover from warfare and regain the strength of the Northern Song. People's enjoyment of the lake showed the country's recovery. Something similar happened in the north, under the Jin Dynasty. The Eight Views of Yanjing 燕京八景, painted around 1260-1264 by Chen Li 陳櫟 (1252-1334), depicts the Jin Southern Capital as flourishing, as I Lo-fen has pointed out. ${ }^{28}$ In both cases, a political point was made by shifting the emphasis from exiled travelers in the Eight Views of the Xiao and Xiang Rivers to the happy sightseers who indulged themselves at the lake.

\section{Maps of West Lake}

The Ten Views also appeared in maps. Such maps would have helped to prevent visitors from inadvertently missing a must-see scene. A detailed sightseeing map of West Lake was included in the local gazetteer published in 1268 (Figure 4.1). This map labels more than 400 famous sites. ${ }^{29}$ The fact that

\footnotetext{
$27 \quad$ Quan Song ci 2.839 .

28 I, "Landscape Like a Picture' and 'Landscape in the Picture," 38-39. In another article on the Eight Views of Beijing, I Lo-fen pointed out that, compared to the Eight Views of the Xiao and Xiang Rivers, which could be categorized as "cultural geography," the Eight Views of Beijing represents "realistic geography." But she also pointed out that not all the paintings on such Eight Views are realistic depictions of the natural landscape; some are painted to invoke recollections of previous poems on the Eight Views. See I, "A New Exploration on Qing Palace's Collection of Ming Dynasty Artists Wang Fu's painting--'The Eight Views of Beijing'," 288.

The map is west-side up, as viewed from Hangzhou city.
} 


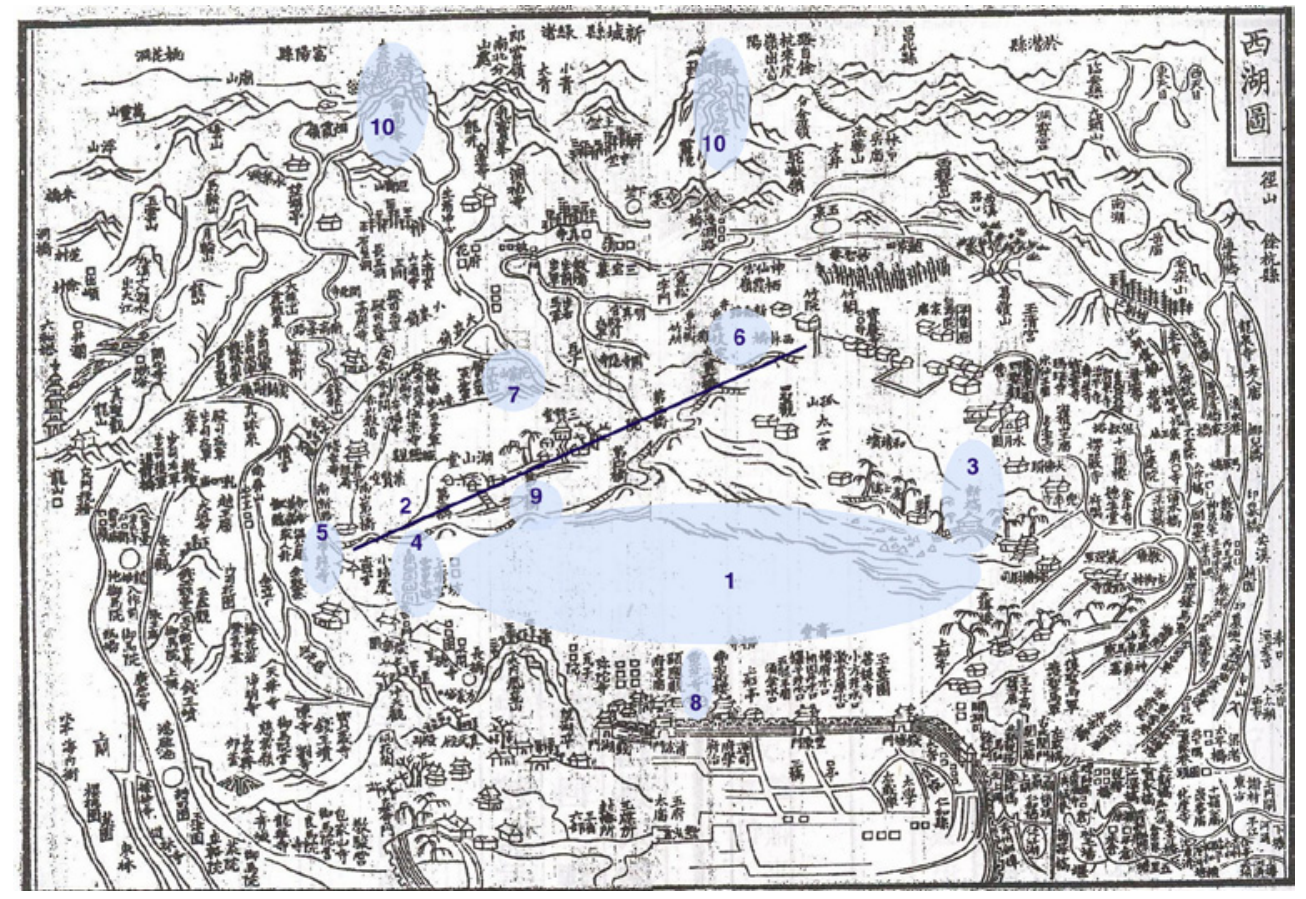

FIGURE 4.1 The ten views noted on the map of West Lake published in 1268. AFTER XIANCHUN LIN'AN ZHI 1.9.

these sites were also recorded in contemporary miscellanies, along with different sightseeing routes, indicates that some sort of shared knowledge was circulating, at least among scholars. ${ }^{30}$

While this gazetteer map stands out for the rich information it provided, other handier maps were much more widely circulated. During the Southern Song Dynasty, travelers who visited Hangzhou always purchased a "guide map" (地經 dijing) of the city at the south-side of the lake, near the White Pagoda. ${ }^{31}$ This was considered something scholars "must do." Guide maps became so popular that someone even wrote a poem on the wall of the pagoda satirizing the buyers and sellers of the maps for caring more about touring Hangzhou than returning to the lost northern capital. From that poem, we know that the guide map had clearly labeled the distances between the West Lake sites. The

\footnotetext{
$30 \quad$ Wulin jiushi, juan 5 .

$3^{1} \quad$ Guhang zaji, 1.1b. The White Pagoda is located on the south of the lake and along the northern bank of the Zhe River, which served as the main waterway used by Song people to get into the city.
} 
name-labels of these famous sites helped promote the visual culture that the Ten Views represented by reconfirming what to see, where to see it, and the geographical relationships between different vistas. The maps not only provided a visual aid for people to imagine the Ten Views in the context of both the lake and the city, but also offered topographical information to facilitate their actual visit. Guide maps are an important manifestation of popular knowledge. They helped their owners to become familiar with the Ten Views, so that the visitors could partake in the activity of gazing at these specific sites.

\section{Paintings of the Ten Views}

The coupling of poems and paintings was a well-established practice in Song times, especially among court painters. ${ }^{32}$ Sometimes the poem came first, other times the painting. Zhao Xigu 趙希鵠 (fl. 1237-1252) contrasted the formation of the Eight Views, the titles of which first came from poets and were later used by painters, with contemporary practice: "Nowadays, painters come up with the titles first, not the scholars." ${ }^{33}$ This association of the Ten Views with painting was confirmed by Wu Zimu 吳自牧 (fl. around 1270) who wrote, "In recent times the ten most spectacular scenes of the four seasons around West Lake and its mountains have been illustrated by painters (近者畫家稱湖 山四時景色最奇者有十). ${ }^{34}$

West Lake scenery was a major inspiration for Southern Song landscape painting. Southern Song painters, such as Liu Songnian 劉松年 (fl. 1155-1218),

The interdependence of poems and paintings has been discussed by many scholars of Song Dynasty art. The practice of using a poem or poetic line as the inspiration for a new work first took root during Huizong's (r. 1100-1125) reign. For examples of painting tests conducted using poetic titles, see Hua ji 1.5. Cahill, "The Imperial Painting Academy," 16o61,165 . For a detailed discussion on the interconnections between poems and paintings in the Eight Views, see Murck, Poetry and Painting in Song China; Ortiz, Dreaming the Southern Song Landscape. Recently, Shih-shan Susan Huang borrowed from W. J. T. Mitchell's discussion of western culture to rearticulate the interlocking relationships between text and image. Huang, Picturing the True Form, 11. This close interaction between poetic images and painting may also explain why most album paintings of the Ten Views since the Southern Song period were based on the practice of pairing poems with paintings. For example, Ming scholar-painter Li Liufang's 李流芳 (1575-1629) Poem and Painting Integration of West Lake 西湖詩畫合璧 (private collection) includes ten paintings with ten poems.

33 Dongtian qinglu ji 1.566.

34 Mengliang lu 12.220. 
Chen Qingbo 陳清波, Ma Lin 馬麟 (fl. 1194-1224), and Xia Gui 夏圭 (fl. ca. 12001240) produced many paintings of West Lake. ${ }^{35}$ The development of landscape painting in turn also contributed to the rise of the custom to compare the lake scenery to landscape painting. The Southern Song Hangzhou literatus Zhou Mi mentioned a scholar who, on his first glance of West Lake, exclaimed: "So beautiful! So unique! The green water is surrounded by blue mountains. The golden and green buildings are situated among the scenery, just like a colorful landscape painting." ${ }^{36}$ Paintings became an effective medium of visual culture for people to communicate what and how they saw.

While handscroll paintings were used to capture panoramic views of the lake's scenery, fan paintings were used to depict specific scenic sites. The account of a Jin embassy to Hangzhou records:

Suddenly, they [the Jin emissaries] turned their heads and looked back at the city's hilly slopes, where houses were stacked layer upon layer. Temples, towers, and terraces of varying heights looked like immortal palaces amidst falling flowers. [The Jin emissaries] got off the carriage and walked along, all enthusiastically praising the vista by saying that inside the city and along the lake were the scenes of a thousand fan paintings.

\section{回頭看城内山上, 人家層層叠叠, 觀宇樓臺參差, 如花落仙宮。下車 步行, 爭說城里湖邊, 有千個局面。37}

The album format (a book-sized set of small paintings bound together) worked well for capturing the Ten Views. It was not until the Southern Song period that album leaf painting became an established and well-represented artistic format. Unlike the long-established handscroll or hanging scroll, which customarily covered a distance beyond what the human eye is capable of absorbing in a single glance, an album leaf painting is a more faithful representation of scenes that are visible within the field of a single observer's vision at a single moment. The formation of the Ten Views as an invention of contemporary painters attests to the importance of framing and selecting scenic elements to form a particular view. Most of the ten titles included diverse elements that are suitable for a painting. The independent but still inter-connected leaves of an album facilitated the presentation of a set number of scenes. This

\footnotetext{
35 Qinghe shuhua fang 3.383a; Jiangcun xiaoxia lu 7.1031; Yanshi shuhua ji 8.51; Nan Song yuanhua lu 2.635; Huishi beikao 6.20b-21a.

$36 \quad$ Guixin zazhi xu.203-4.

37 Fansheng lu 122-123. The translation is from Lee, Exquisite Moments, 19.
} 
also partly explains why the Ten Views throughout its history were usually depicted in the format of a ten-leaf album.

The fact that each composition was painted as part of a set made it easier for viewers to identify each leaf. Specific landmark features function as indicators of which view each album leaf is depicting and can effectively trigger viewers' mental images of the site, even though the rest of the compositional elements are not very realistic. ${ }^{38}$ However, if a leaf was separated from the album for any reason, it would be difficult to be sure it belonged to a set or which scene it depicted. ${ }^{39}$

The Southern Song academy painters produced several sets of the Ten Views, and some artists created more than one. ${ }^{40}$ Yet, despite this known production, Ye Xiaoyan's 葉尚嚴 (fl. around 1253-1258) album is the only extant Song period depiction. ${ }^{41}$ Little is known about Ye, and his Ten Views album is his only surviving work. Ye's debts to Ma Yuan 馬遠 (fl. ca. 119o-1264) and Xia Gui can be seen in this album in his frequent application of the axe-cut textual stroke and his rendering of misty scenery in a distinctive way. Recurring themes and visual elements, and the use of particular techniques were all essential in reproducing and reinforcing the characteristic visual culture of West Lake.

It is quite possible that Ye's paintings of the Ten Views were closely based on or even copied from an earlier masterpiece. James Cahill argued that a fresh pictorial conception created by one of the major masters within the academy might have spread outward through copies and imitations in response to

38 Amy Huang, in her discussion of Ming paintings of real scenery in Nanjing, identified a similar practice among those painters. She used the term "synecdoche" to describe the practice: it means a part of something is used to refer to the whole of it. Huang, "Nature, Fengshui, and Political Symbolism."

39 There are untitled album leaves from the Southern Song period that are reminiscent of the titles of the Ten Views, such as Travelers at Dusk-a Southern Song painting now in the Museum of Fine Arts, Boston (for an image of it, see Lee, Exquisite Moments, 67). Both Barnhart and Lee suggested that it is very likely a depiction of "Evening Bell from Nanping Hill" because the topographical features firmly place the scene at West Lake, and the composition is close to Ye Xiaoyan's painting (Figure 4.14). Barnhart, "Shining Rivers," 56; Lee, Exquisite Moments, 66. Lee also suggested that another two album paintings possibly depict the Ten Views. One is Ma Yuan's Bare Willows and Distant Mountains, also now in the Museum of Fine Arts, Boston. The willows and their relative position in this painting indicate that the painter was possibly depicting the Assembling Scenery Garden-the place in "Listening to the Orioles by the Willow Ripples." The other is an anonymous fan painting now in the Metropolitan Museum of Art, titled Boating by a Willow Bank. The depiction of round lotus leaves reminds viewers of Ye Xiaoyan's album leaf on "Lotus Breeze at Qu Winery." See Lee, Exquisite Moments, 68-69, 108-o9.

$40 \quad$ Jiangcun xiaoxia lu 7.1031. Nansong yuanhua lu 8.635.

41 For plate illustrations, see Gugong shuhua tulu 22.74-79. 
market demand. ${ }^{42}$ In Hangzhou, styles popular among the court painters quickly spread to ordinary consumers. If Ye's painting was based on another lost masterpiece, this could explain the discrepancy between the thoughtful arrangement of the visual elements and his less impressive brushwork.

Depictions of the Ten Views of West Lake and the Eight Views of the Xiao and Xiang Rivers reveal clear influences from one another. ${ }^{43}$ Some Southern Song painters, such as the monk Muqi 牧谿 (ca. 1200-after 1279), based their painting of the Eight Views on their observations of West Lake scenery. ${ }^{44}$ This practice in turn encouraged painters to borrow inspirations from Eight Views paintings when they depicted the Ten Views. For example, Ye Xiaoyan's leaf "Listening to the Orioles by the Willow Ripples" (Figure 4.2) echoes Monk Muqi's album leaf "Returning Sail off Distant Shore" (Figure 4.3), with the depiction of a nearby lakeshore and a misty rendering of distant waters. ${ }^{45}$ Similarly, it is widely believed that Xia Gui's Twelve Views of Landscape was influenced and inspired by paintings of the Eight Views (see Figure 4.4). ${ }^{46}$ Though the four scenes which are extant today are mistier and feature less concrete forms than the images in Ye's album, the shape of the mountain, the use of trees to signify the lakeshore, and the mountain silhouettes are all very similar.

Though influenced by paintings of the Eight Views, Ye's painting demonstrates very different intentions. Hui-Shu Lee argued that Ye's utmost concern was to make sure that the ten leaves could be easily identified. ${ }^{47} \mathrm{He}$ thus made every effort to convey the information in each title by appropriating and arranging varying visual elements such as trees, mountains, buildings, and figures in the miniature format. Compared to other sites, West Lake's accessible location meant that painters could observe it up close, given the academy's

42 Cahill, The Lyric Journey, 42; "The Imperial Painting Academy," 169. He also suggests that the imitation could also go the other way, as local artists could bring their traditions with them when they were summoned to court.

Richard Barnhart suggested in his discussion of the Eight Views, "While the new ten views focused on the distinctive scenery of West Lake, it is clear that the earliest painters of the subject were fundamentally influenced by the popular tradition of the eight famous views of Hsiao and Hsiang in creating compositions." Barnhart, "Shining Rivers," 55.

44 Lee, Exquisite Moments, 12.

45 For further information on Figure 4.2, see Li, "Ye Xiaoyan de xihu tu ji qita." For further discussion on Figure 4.3, see Barnhart, "Shining Rivers," 51 (Fig. 26).

46 I, “'Landscape Like a Picture' and 'Landscape in the Picture," 52.

47 Lee, "The Domain of Empress Yang," 305. 


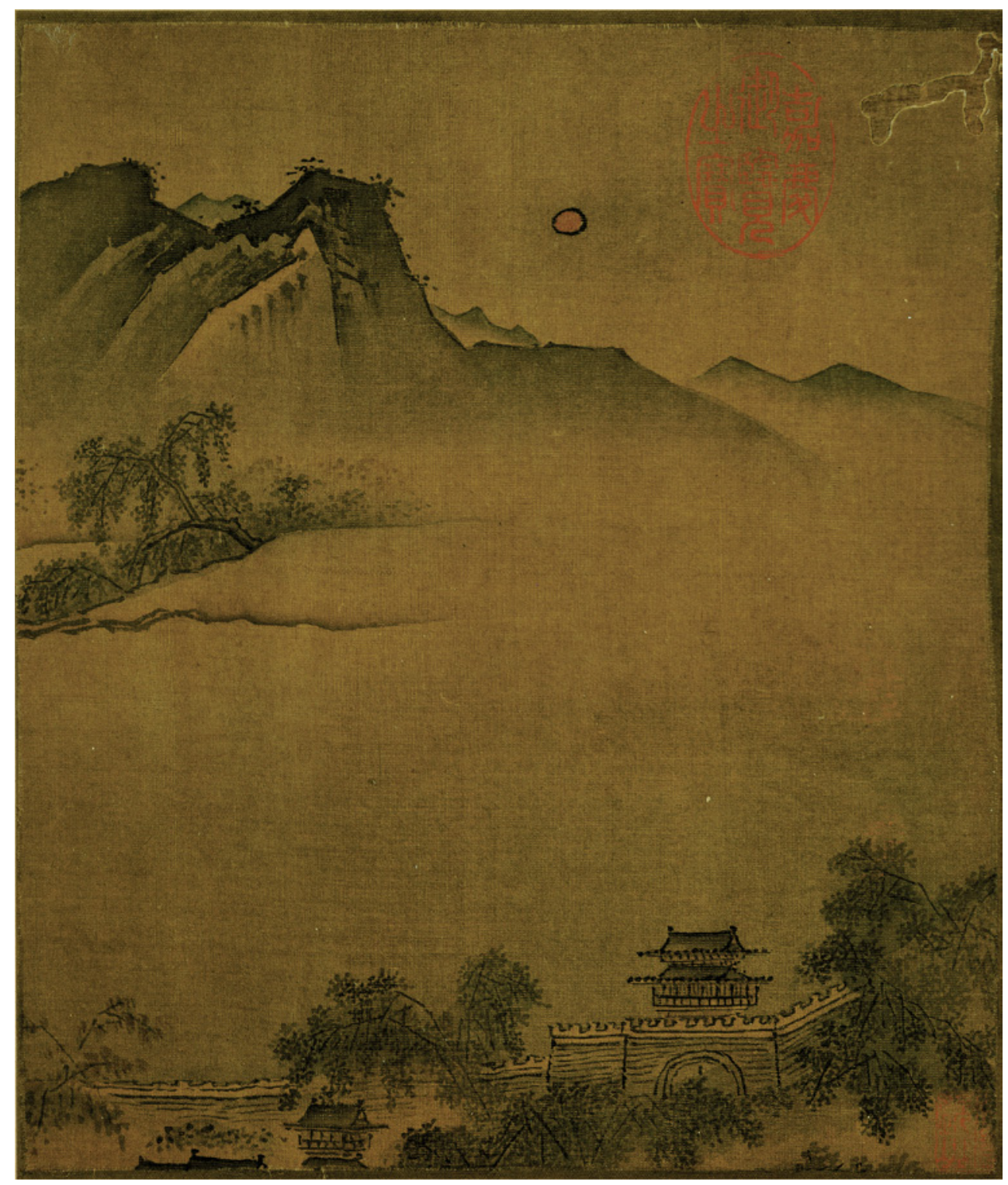

FIGURE 4.2 YeXiaoyan, Listening to the Orioles by the Willow Ripples; ink on paper; H: 23.9, $W: 20.2 \mathrm{~cm}$; NATIONAL PALACE MUSEUM, TAIPEI. 


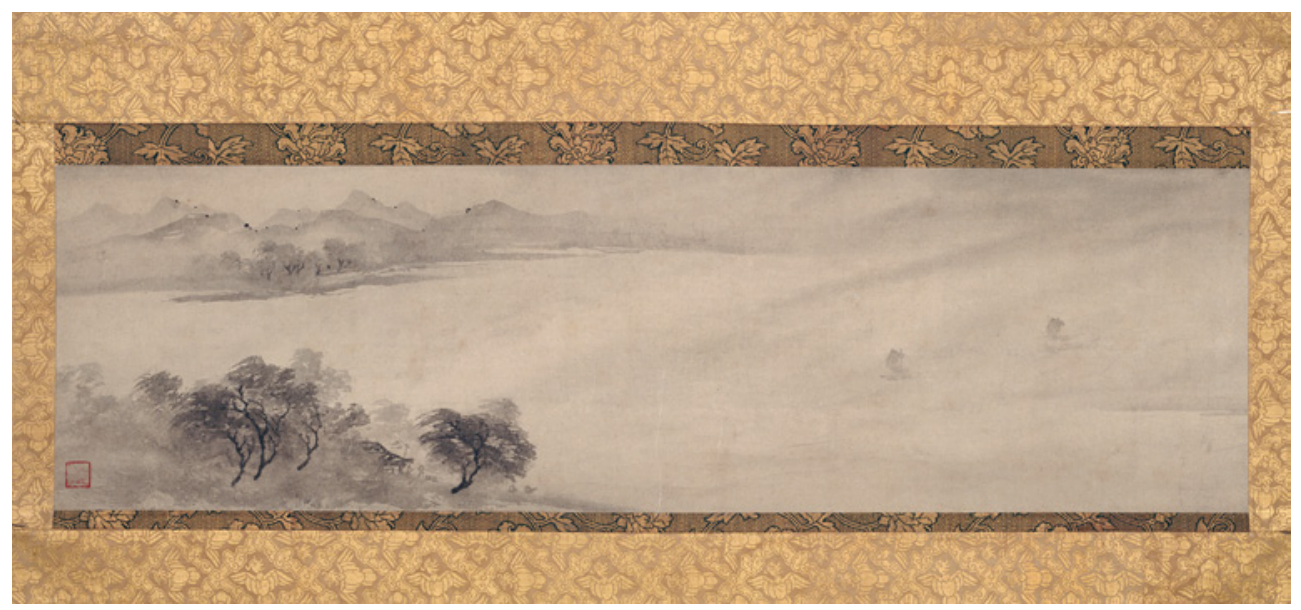

FIGURE 4.3 Monk Muqi, Sail Returning from Distant Shore; ink on silk; H: 32.3, W: $103.6 \mathrm{~cm}$. IMAGE COUNTESY OF THE KYOTO NATIONAL MUSEUM.

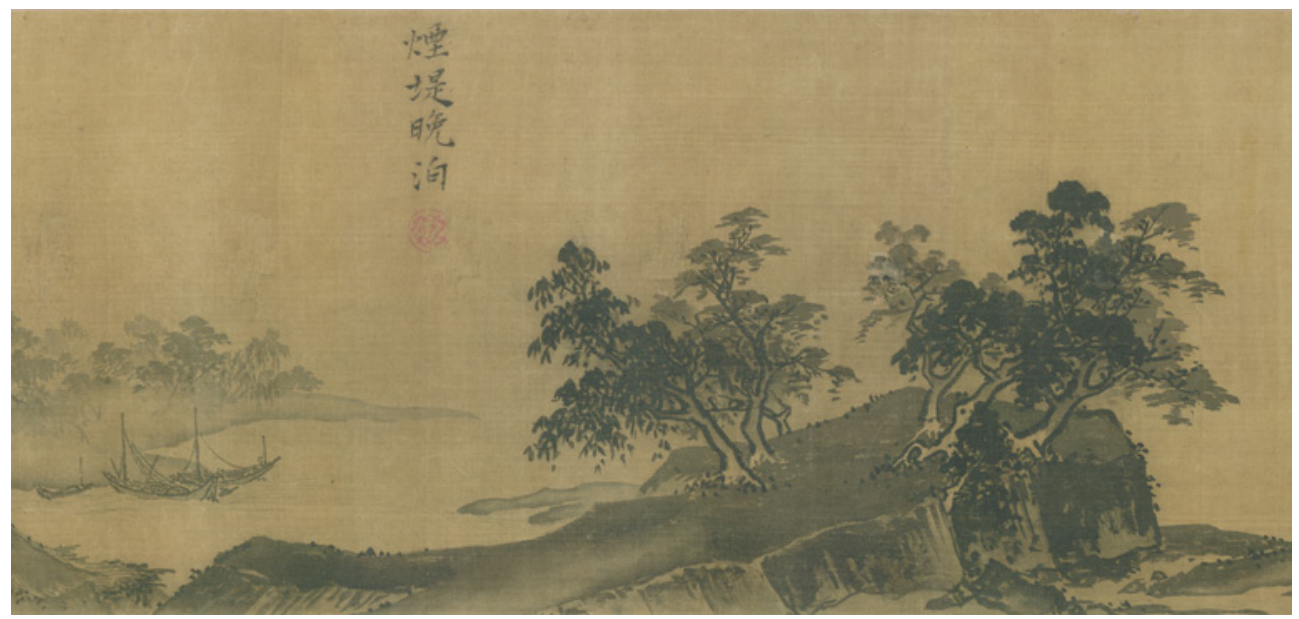

FIGURE 4.4 Xia Gui, Twelve Views of Landscape (part); ink on paper; H: 28, W: $230.5 \mathrm{~cm}$. IMAGE COUNTESY OF THE NELSON-ATKINS MUSEUM OF ART.

very close proximity to the Watching River Gate, on the east bank of West Lake. $^{48}$

As can be seen in Table 4.1, many of the Ten Views are based on specific physical sites or structures, such as Leifeng Pagoda (Figure 4.5), Jingci Monastery 淨慈寺, and Su Dike. Ye made these locations the foci in his paintings. Even images lacking specific identifying features contain clues that link

48 Chen, Nansong huihua shi, 53-56.

For use by the Author only | (C) 2017 Koninklijke Brill NV 


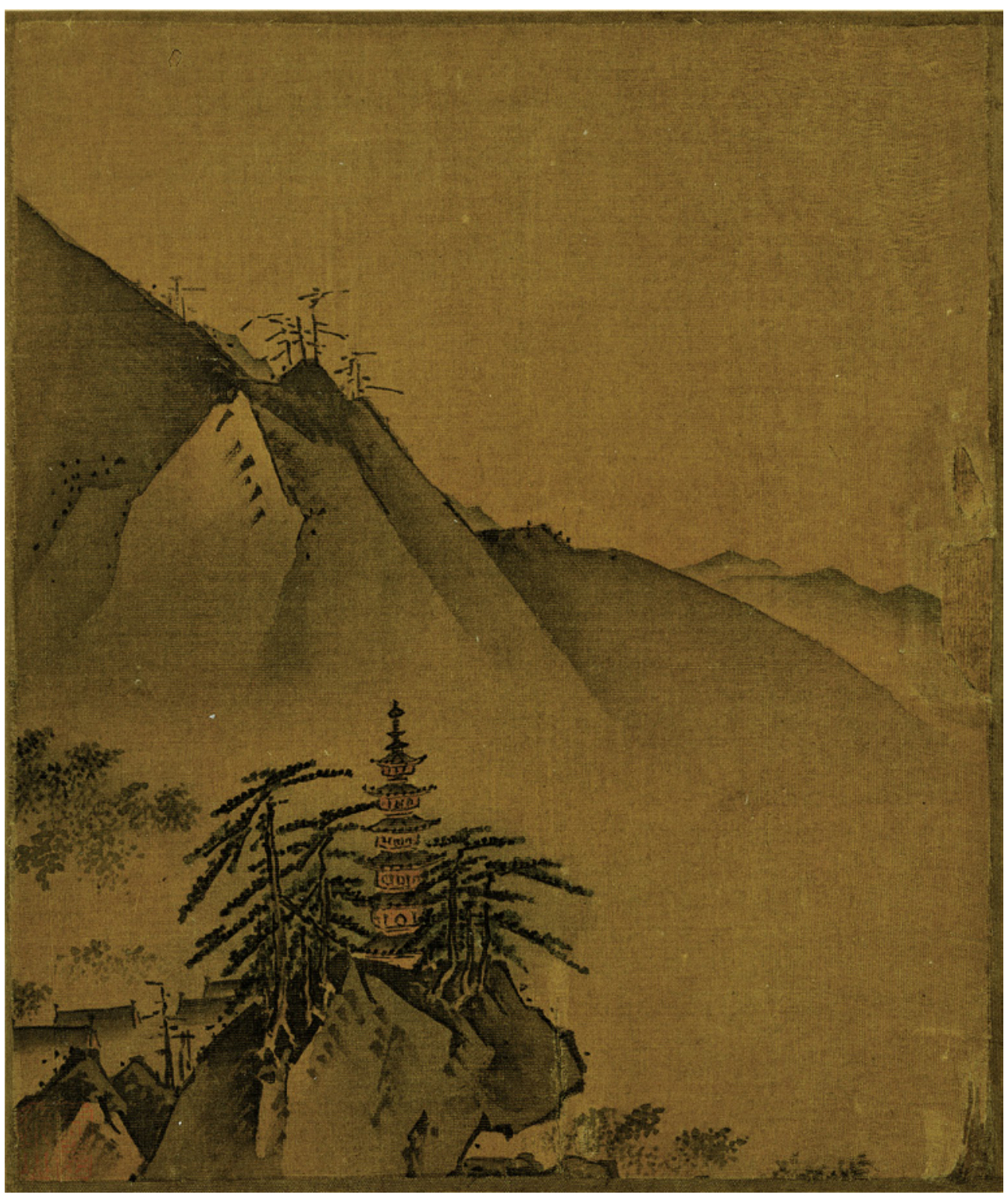

FIgURE 4.5 Ye Xiaoyan, Sunset on Leifeng Pagoda; ink on paper; H: 23.9, W: 20.2 cm; NATIONAL PALACE MUSEUM, TAIPEI.

For use by the Author only | (C) 2017 Koninklijke Brill NV 


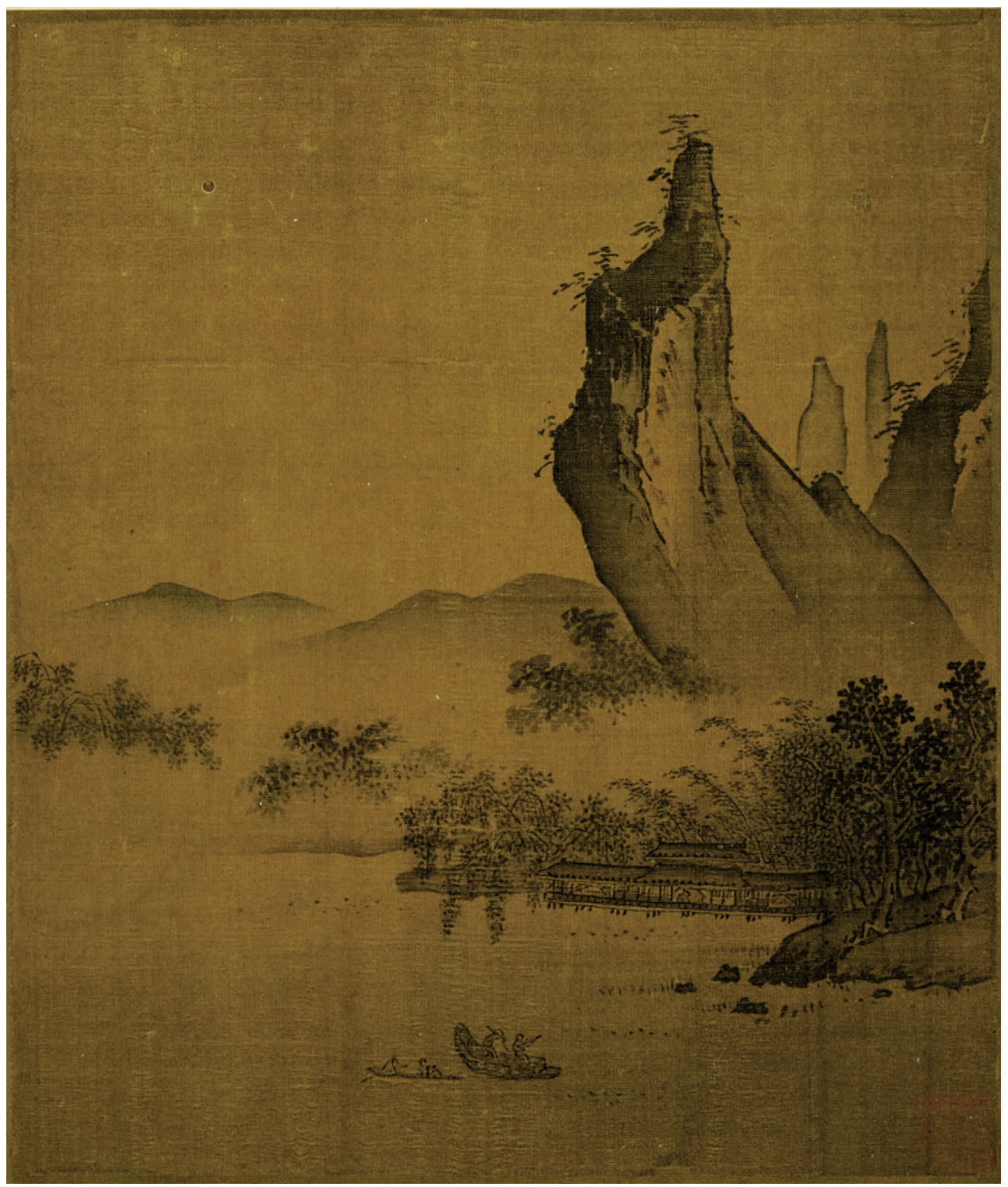

FIGURE 4.6 Ye Xiaoyan, Autumn Moon above the Placid Lake; ink on paper; H: 23.9, W: $20.2 \mathrm{~cm}$; NATIONAL PALACE MUSEUM, TAIPEI.

For use by the Author only | (c) 2017 Koninklijke Brill NV 


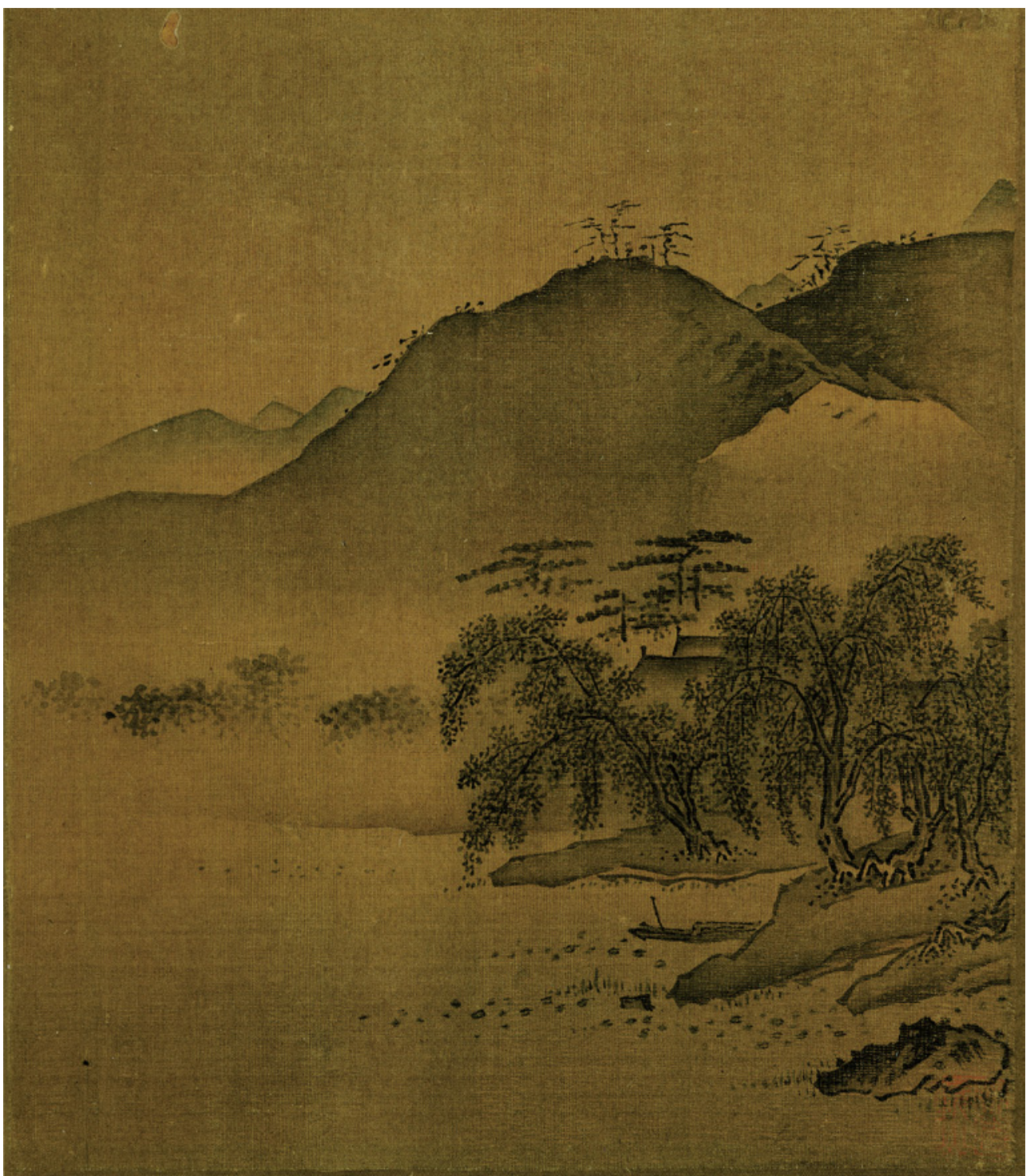

FIGURE 4.7 Ye Xiaoyan, Lotus Breeze at Qu Winery; ink on paper; H: 23.9, W: $20.2 \mathrm{~cm}$; NATIONAL PALACE MUSEUM, TAIPEI.

For use by the Author only | (C) 2017 Koninklijke Brill NV 


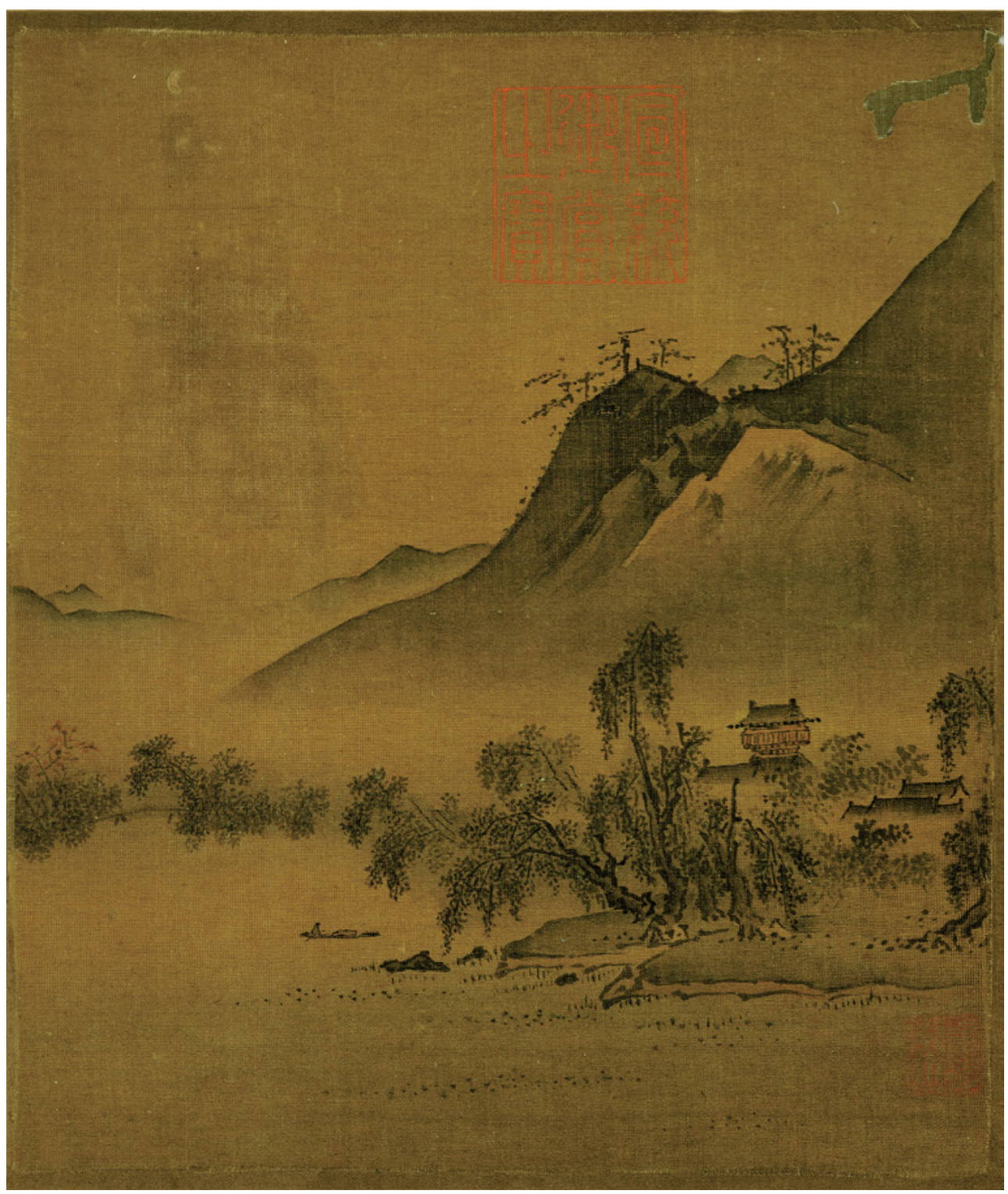

FIGURE 4.8 Ye Xiaoyan, Watching Fish at Flower Cove; ink on paper; H: 23.9, W: $20.2 \mathrm{~cm}$; NATIONAL PALACE MUSEUM, TAIPEI.

For use by the Author only | (c) 2017 Koninklijke Brill NV 
the depicted scenery to a specific View. For instance, in "Autumn Moon above the Placid Lake," while there is no specific landmark to identify the "Placid Lake," Ye depicted a sharply obtruding peak intended to contrast with and therefore attract the viewers' attention to the calm lake (Figure 4.6). Specific depictions of plants and uses of color also help the viewer identify the scene. The leaves corresponding to "Lotus Breeze at Qu Winery" (Figure 4.7) and "Watching Fish at Flower Cove" (Figure 4.8), for instance, are quite similar at first glance, but Ye was able to use round lotus leaves to make a further distinction.

The clear emphasis on place in the Ten Views was not a Southern Song innovation. The Tang painters Wang Wei 王維 (699-759) and Lu Hong 盧鴻 (fl. 740s) painted pictures of their own gardens, as did the Northern Song painter Li Gonglin 李公麟 (1049-1106), as is reflected in versions of the Mountain Villa, which have been attributed to him (Figure 4.9). ${ }^{49}$ Each of the ten album leaves in Lu Hong's Ten Images of My Grass Hut has a site name, such as "Writing Grass Hall" or "Expecting Immortal Steps," and includes a figure sitting or wandering in the landscape (Figure 4.10). ${ }^{50}$ Each album also features a short description of the site's geography and history, followed by one or two poems related to the place. Both the format of ten associated album paintings and the emphasis on the representation of actual sites with figures suggest a possible inspiration for the Ten Views at West Lake. What differentiates Ye's painting from these predecessors was his apparent assumption that the viewers already knew the site. While Lu Hong's and Li Gonglin's paintings offer an illustrated introduction to these sites, Ye's depiction is less topographic. It was natural for viewers who had been to West Lake, or at least had read poems about its famous attractions, to notice these "signposts" around the lake.

The emphasis on physical sites also enabled the painter to represent the scenery in a closer and more intimate way. A comparison of Ye's painting with Li Song's 李嵩 (1166-1243) handscroll (Figure 4.11), which also includes most of the Ten Views (labeled on the image), reveals an alternative way to direct the perspective of viewers. Taking a bird's-eye view, Li Song ambitiously represented the entire lake from a high and distant standpoint. In Ye's painting of "Spring Dawn at Su Dike" (Figure 4.12), instead of trying to show the entire Su Dike, he rendered only one of the six bridges that connected the dike. These techniques helped to draw viewers close to the scenery to create an intimate

\footnotetext{
49 For a study of the various extant versions of the Mountain Villa, see Harrist, Painting and Private Life in Eleventh-Century China.

$50 \quad$ For studies of Lu Hong's Ten Images of My Grass Hut, see Zhuang, Tang Lu Hong caotang shizhi tu juan kao; Wu, "Lu Hong ji qi huaji wei e yuanliu kaojian."
} 


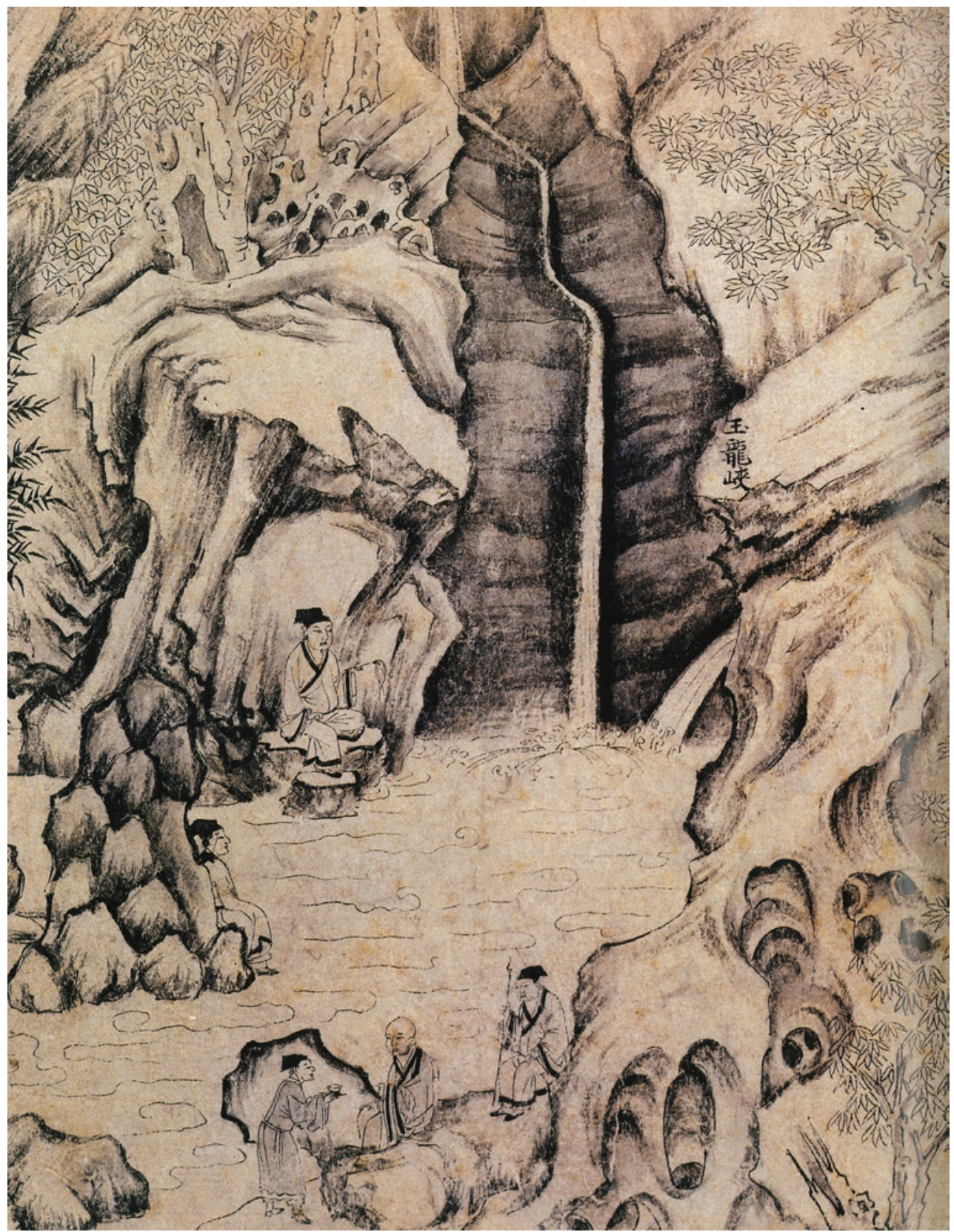

FIGURE 4.9 Li Gonglin, Mountain Villa, ink on paper. H: 28.9, W:364.6 cm; NATIONAL PALACE MUSEUM, TAIPEI. AFTER DAGUAN: BEISONG SHUHUA TEZHAN, 97-100. 


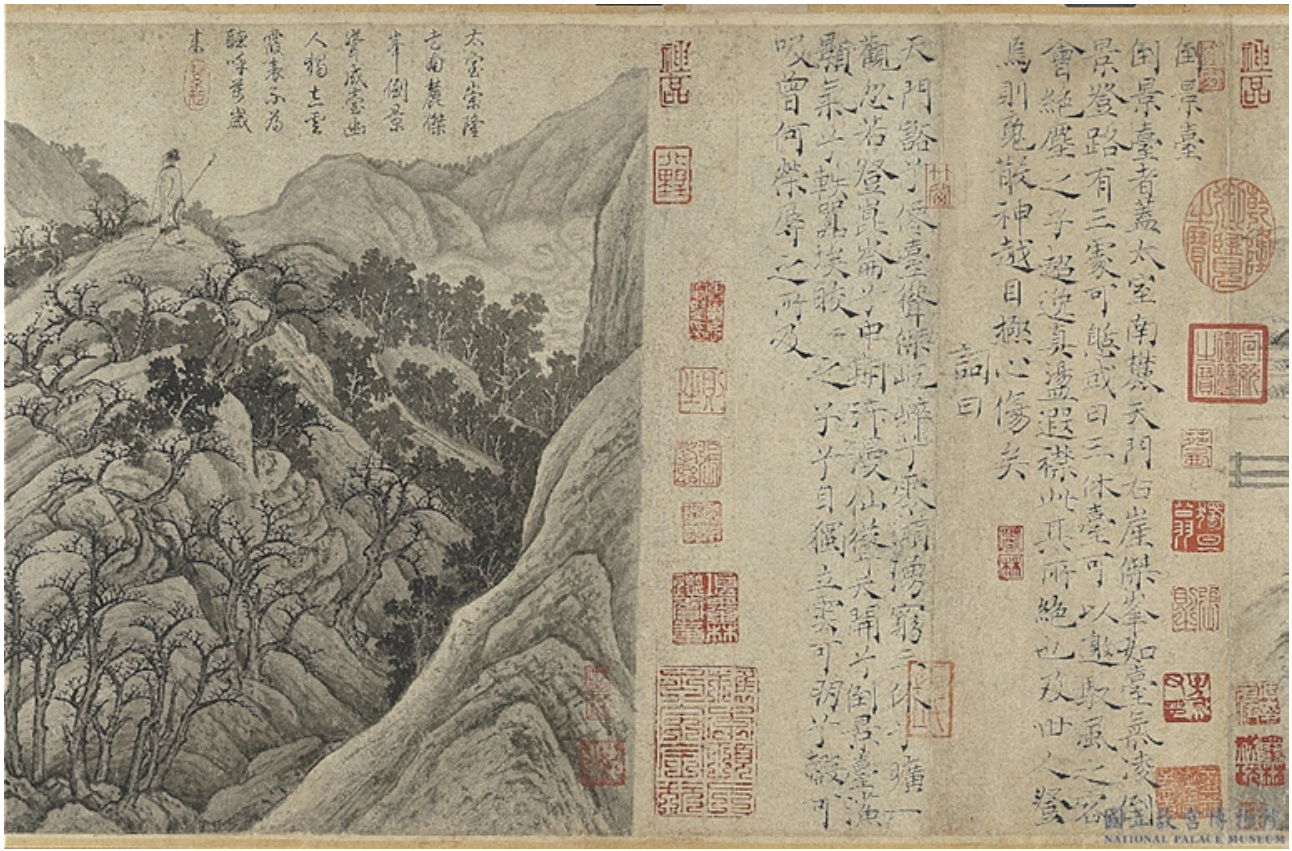

FIGU RE 4.10 Lu Hong, Reflecting Scenery Altar; ink on paper; H: 29.4, W: 6o cm; NATIONAL PALACE MUSEUM, TAIPEI.

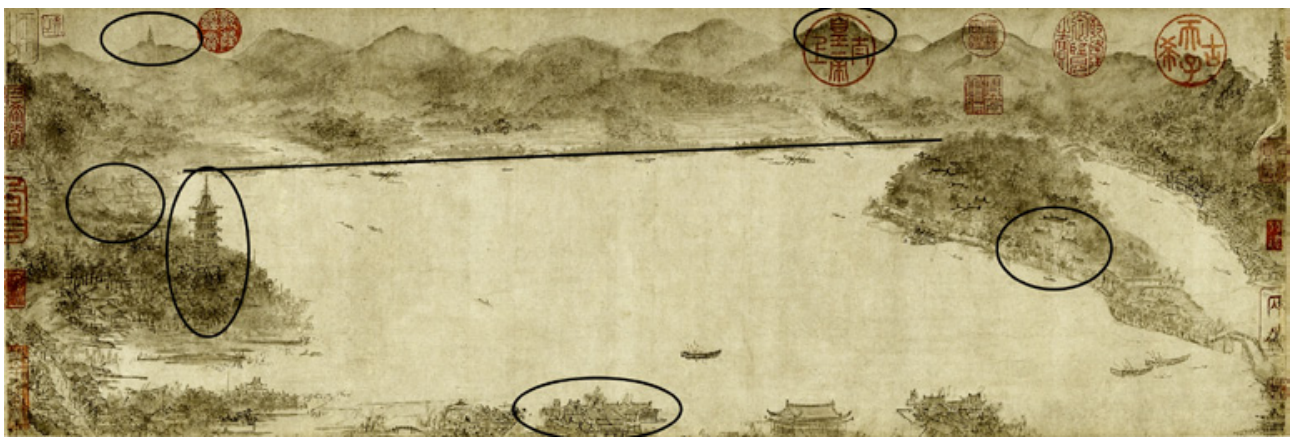

FIGURE 4.11 Li Song, West Lake, ink and color on paper; H: 27, W: $80.7 \mathrm{~cm}$; SHANGHAI MUSEUM. 


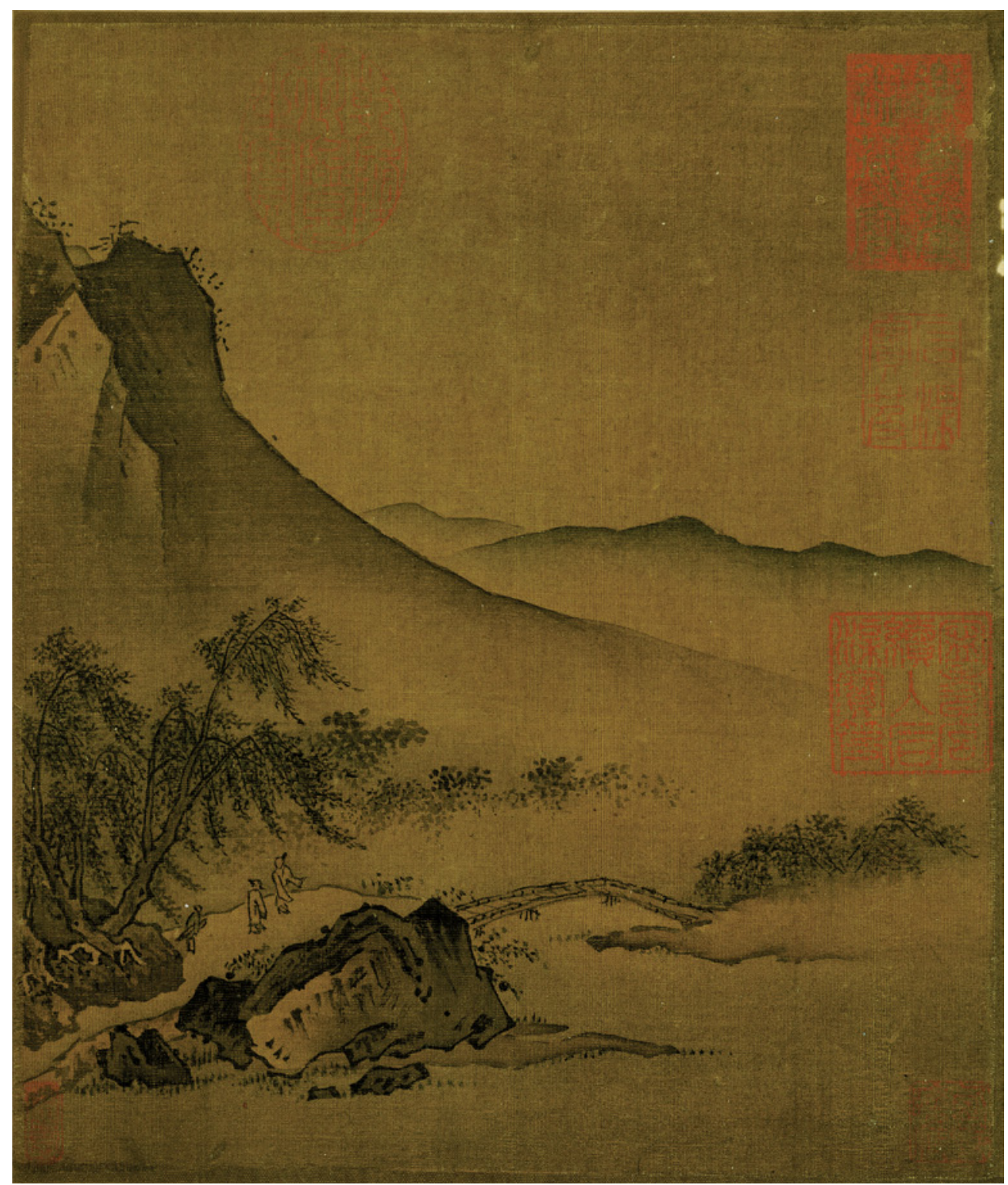

FIGURE 4.12 Ye Xiaoyan, Spring Dawn at Su Dike; ink on paper; H: 23.9, W: 20.2 cm; NATIONAL PALACE MUSEUM, TAIPEI.

For use by the Author only | (C) 2017 Koninklijke Brill NV 


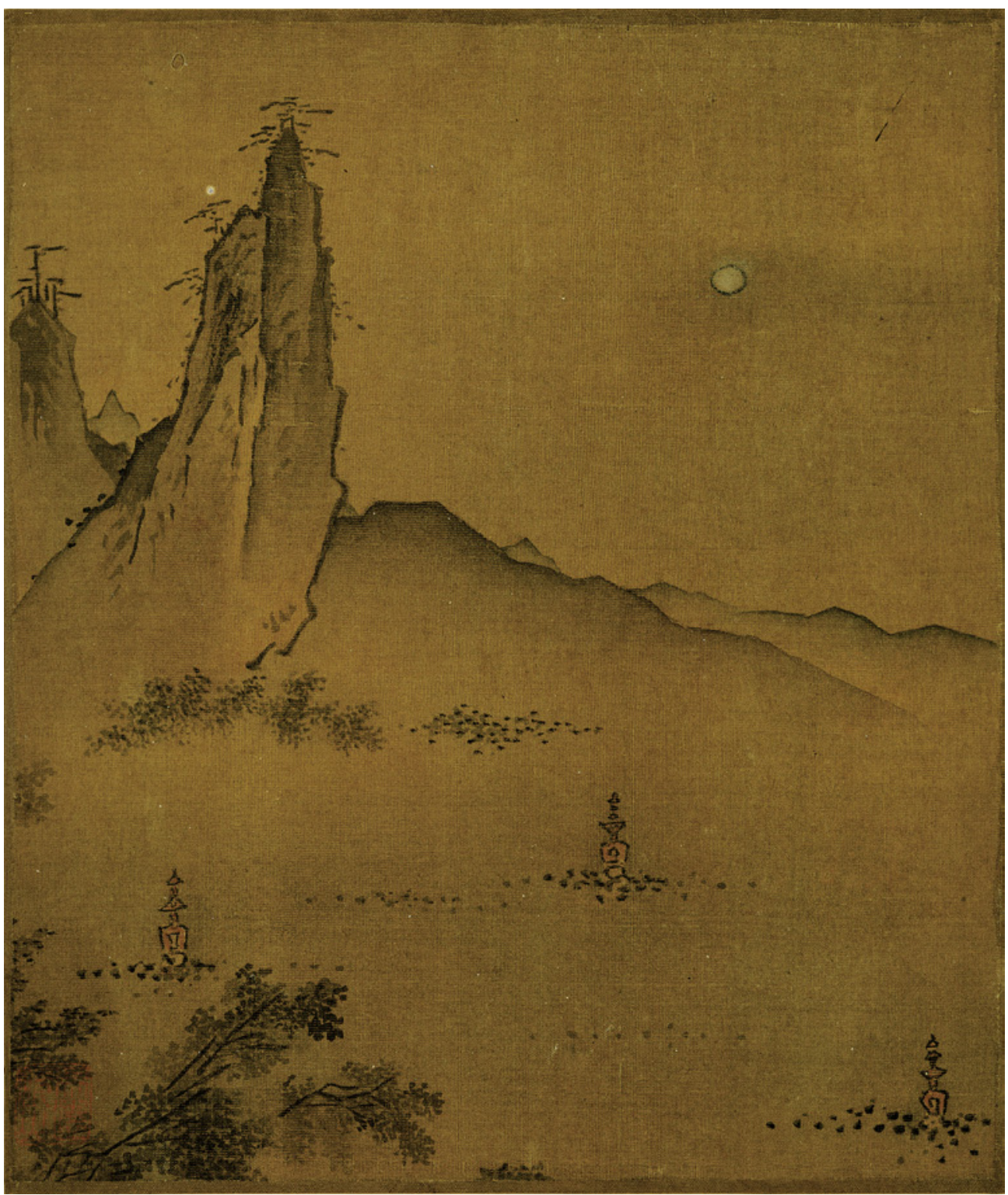

FIGURE 4.13 Ye Xiaoyan, Three Stupas and the Reflecting Moon; ink on paper; H: 23.9, W: 20.2 $\mathrm{cm}$; NATIONAL PALACE MUSEUM, TAIPEI.

For use by the Author only | (C) 2017 Koninklijke Brill NV 


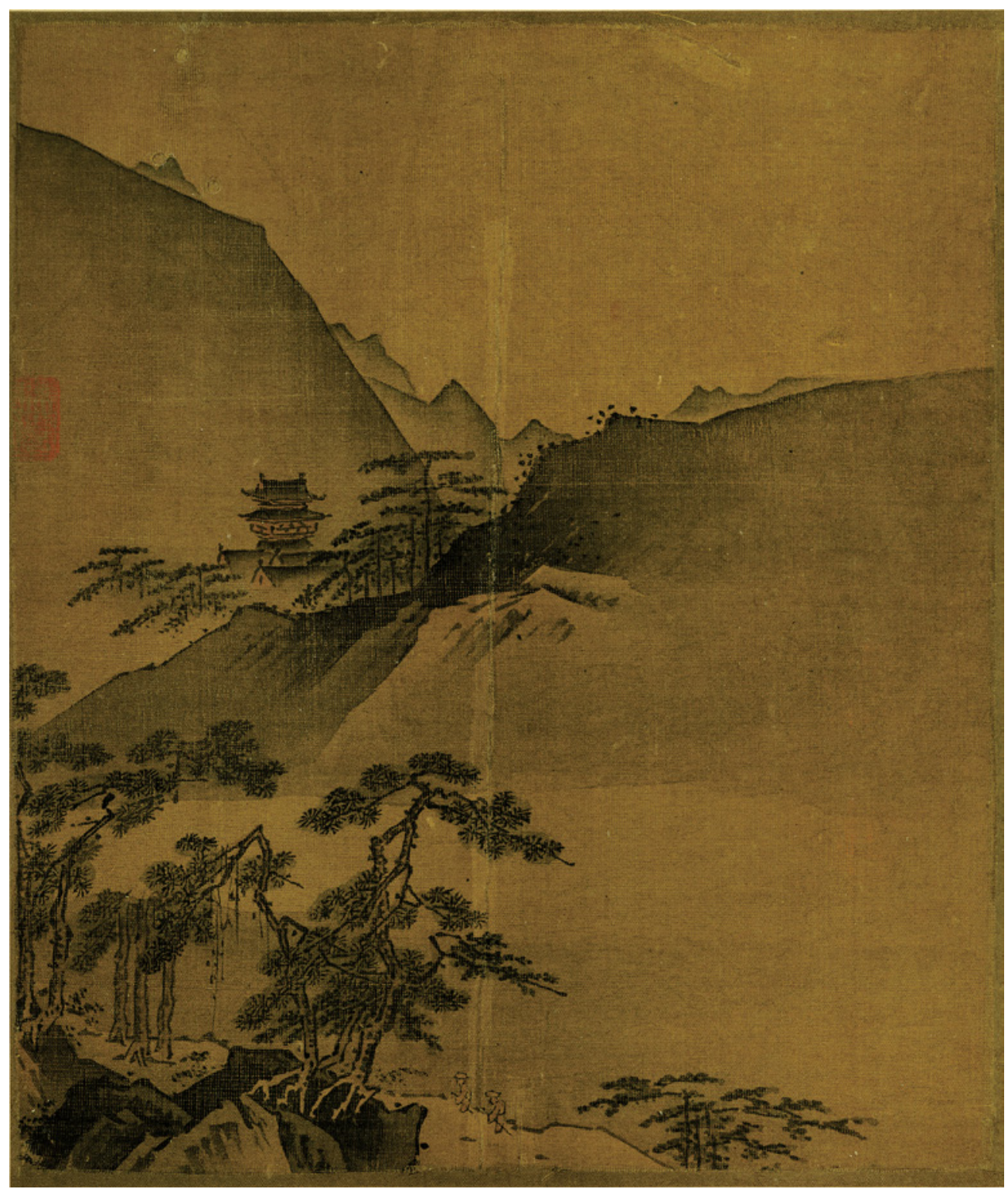

FIGURE 4.14 Ye Xiaoyan, Evening Bell from Nanping Hill; ink on paper; H: 23.9, W: $20.2 \mathrm{~cm}$; NATIONAL PALACE MUSEUM, TAIPEI. 
atmosphere. Some other leaves, although still influenced by Li Song's bird'seye view, were designed to provide a zoomed-in effect; examples of this approach are "Three Stupas and the Reflecting Moon" (Figure 4.13) and "Evening Bell from Nanping Hill" (Figure 4.14). This zooming-in technique enhanced the viewers' affective bond and personal identification with the place.

Viewers were not only brought closer to specific sites but were also deliberately represented in the paintings. Some views, such as "Watching Fish at Flower Cove" (Figure 4.8), have the sightseeing activity in the title. Here, Ye posed the figure who is boating on the lake in a leisurely manner, and directed the viewers' attention to the open surface of the lake. ${ }^{51}$ In Southern Song paintings, a boat was usually interpreted as "the connection of the owners with the outside world" because it recalled the reality of traveling via waterways. ${ }^{22}$ A sense of connection with the outside world was also depicted in paintings in the way the figure of the featured visitor was posed. Their position usually would direct the viewers' gaze to the natural scenery and/or to the structure emphasized in the title. In the painting "Spring Dawn at Su Dike" (Figure 4.15), for example, Ye placed three figures on one side of the bridge: two are dressed as literati and one as a servant. One of the literati is turning his head towards the other and is pointing to the bridge, as if proposing to cross it. This arrangement of figures functions as an invitation to viewers to place themselves in the painting. Other Views, such as "Three Stupas and the Reflecting Moon" (Figure 4.13) and "Twin Peaks Piercing the Clouds" (Figure 4.16), are depicted from a considerable distance. Instead of adding figures directly into these paintings, Ye rendered these two vistas as if the viewers of the album were standing right in front of the scenic sites. Thus, the viewers can imagine themselves as the suggested (but un-pictured) gazers visiting the location.

Nature in Ye's album is "idealized and secure," due to his thoughtful arrangement of visual elements; this reflects Southern Song landscape conventions. ${ }^{53}$ His album representations of the ten titles follow a style that was fashionable in Southern Song academy painting. In other words, his visual representations of the Ten Views are influenced by artistic traditions, and at the same time also evoke and echo the actual sightseeing experience. Based on such experiences, viewers of the paintings could decode Ye's visual clues to discern the identity

This also differentiates it from "Lotus Breeze at Qu Winery" (Figure 4.7), in which only an empty boat is added under the willow trees, partly because no specific activity is mentioned in the title.

52 Cahill, "The Imperial Painting Academy," 181.

53 Cahill, "The Imperial Painting Academy," 173. 


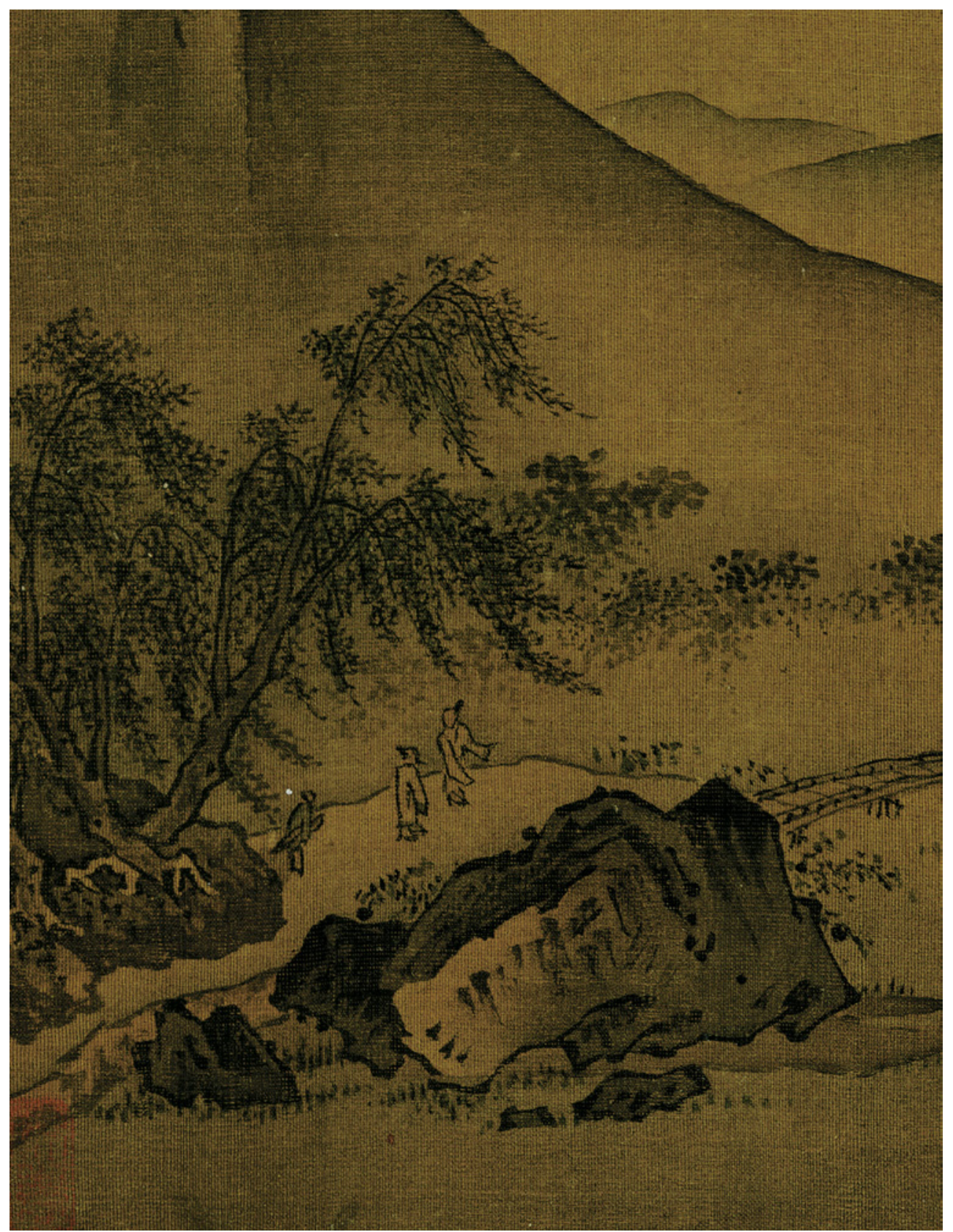

FIGURE 4.15

Ye Xiaoyan, Spring Dawn at Su Dike (detail); ink on paper; H: 23.9, W: $20.2 \mathrm{~cm}$; NATIONAL PALACE MUSEUM, TAIPEI.

For use by the Author only | (c) 2017 Koninklijke Brill NV 


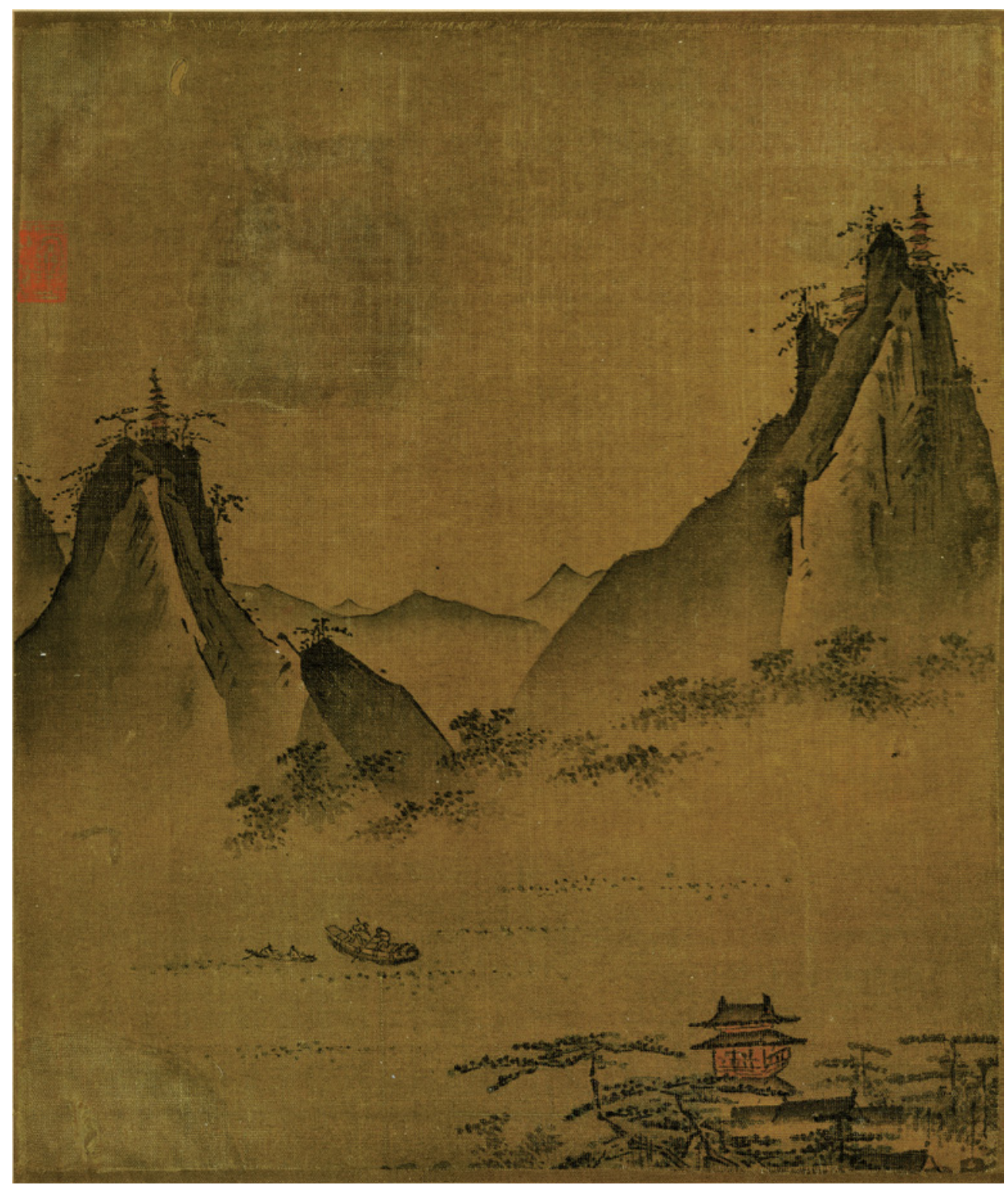

FIgURe 4.16 YeXiaoyan, Twin Peaks Piercing the Clouds; ink on paper; H: 23.9, W: $20.2 \mathrm{~cm}$; NATIONAL PALACE MUSEUM, TAIPEI.

For use by the Author only | (c) 2017 Koninklijke Brill NV 
of each view, which offers them a sense of accomplishment. People familiar with the skyline of New York can easily recognize the Empire State Building for its unique shape and its frequent appearance in photos. Southern Song visitors to West Lake must have had a similar experience: standing beside the lake, when they look at the distant hills, two peaks will stand out because of the two pagodas located there (Figure 4.16); and if one looks at the Southern Hill, the silhouette of Leifeng Pagoda and the eaves of Buddhist monasteries revealed behind the trees will grab the viewer's attention (Figure 4.5). Both the depiction and identification of nature in the album paintings called the viewer to come to the actual site in order to spiritually join others who do the same and thus created a community based around a place.

The seasonal dimension of the Ten Views is worth further discussion as it offers clues to what to see during particular times. As can be seen in Table 4.1, among the titles of the Ten Views, two are about spring and one (each) is about summer, autumn, and winter. Based on her analysis of album paintings, Huishu Lee argued that Ye's paintings of the Ten Views manifest a theme commonly seen in Southern Song paintings: the articulation of seasonal moods. ${ }^{54}$ Many Southern Song paintings were devoted to the depiction of seasonal scenery and activities, such as Liu Songnian's Siji Landscape Painting of the Four Seasons and Xia Gui's Clear Summer among the Lotus. Several literary works also were arranged according to the annual calendar. ${ }^{55} \mathrm{Wu}$ Zimu, in his records of the Ten Views, rearranged the sequence of the ten titles so that they would better correspond with the natural order of seasons and times. ${ }^{56}$

In addition to sensitivity towards seasonal changes, the Ten Views also suggest a fondness for capturing transient moments such as dawn and dusk. Southern Song writers loved to lament the loss of youth (youth was traditionally symbolized by early morning and early spring), and the transient nature of the physical world. In his discussion of Southern Song paintings, Max Loehr stated, "such condensed moments were expressed in events like sunset, dusk, and nightfall; a breeze, gust of wind, or squalls; a sudden shore, a gentle rain, or clearing skies. ${ }^{n 7}$ Martin Powers also argued that changes of time became a

54 Lee attributed this feature to imperial interest in Daoism and Chan Buddhism, both of which emphasized an awareness of the transience of the human world. Lee, Exquisite Moments, 41-42.

For more discussion on the compiling style of these miscellanies, see West, "The Interpretation of a Dream" and de Pee, "Nature's Capital."

$56 \quad$ Mengliang lu 12.216-217, The translation is from Lee, Exquisite Moments, 32.

57 Loehr, The Great Painters of China, 191. 
fit subject for artists' brushes in the Southern Song period, when the paintings tended to "privilege the viewer's subjective experience." 58 It was very common for travelers to notice seasonal changes during their regular visits throughout the year, and to combine this with comments especially on flowering plants. As Wu Zimu noted, city dwellers would pay visits to the lake during several festivals in the spring, summer, and autumn. ${ }^{59}$ From dawn to dusk, the passing of time enabled the sightseers to perceive the concurrent changes in light, shadow, mist, and wind. The same pagoda appears more vivid against a sunset, especially when sightseers are at the same time also saying goodbye to the lake on their way back home. The ten titles advertised the greatest touring and gazing experience by pointing out the best time for enjoying each site: for example, $\mathrm{Qu}$ Garden is always blessed with the smell of wine floating in the wind, but it would be best if accompanied by the smell of lotus flowers in the summer.

Time not only functioned as the most important coordinate in one's memory, but also endowed the Ten Views with universal meanings. People respond in similar ways to watching the sunset or seeing the reflection of the moon on water. These shared reactions made it easier for people who have never been to the lake to imagine themselves standing on its shore. Just as the album paintings framed visual images of the vistas, the ten titles offered a framed way of seeing and experiencing nature. ${ }^{60}$

\section{Conclusion}

This study has drawn on poems, maps, and paintings to explore the cultural practice of epitomizing the experience of nature at West Lake in terms of fourcharacter poetic titles - titles that capture scenes. The visual culture of West Lake was produced, reproduced, and circulated in multiple forms of media by numerous actors. In this culture-building process, the interplay and tension between text and image became pervasive, and neither texts nor pictures alone dominated people's interpretations of the lake. Rather, words and images

$5^{8} \quad$ Powers, "Picturing Time in Song Painting and Poetry," 66-67.

59 For example, the Qingming Festival, the Cold Food Festival, the Double Fifth Festival, and the Birthday of Lord Cui. For more discussion on festivals, see Duan, "Scenic Beauty outside the City," 145-55.

60 As Jacques Lacan argued, gaze usually happens in the presence of others. So at the very moment that people were gazing at the ten vistas, both the real ones and the painted ones, the interaction was no longer between an individual and pure nature. Gaze, as Lacan contends, reduces the power of the objective while empowering the subjective by providing a tool to order the objective. Lacan, The Four Fundamental Concepts, 84-85. 
merged in their influences on the viewers and upon each other to capture ephemeral moments and to associate them indelibly with this cultural landmark. Given the wide circulation of poems and pictures of West Lake, even those who failed to pay a physical visit could enjoy a virtual experience of it. In this way, the people could share a uniting set of memories that also could have individual and even nostalgic resonances for anyone who contemplated this showplace garden of the new capital.

The practice of giving poetic names to scenic spots lasted much longer than the Song Dynasty. But beginning in the Southern Song period, the convention of using ten views to present local scenery became a countrywide practice and even spread to Japan and Korea. ${ }^{61}$ This was because the practice served both to reinforce local pride and to help any visitor to feel more familiar within the landscape. Eventually, local gazetteers for almost every county in the country would include a section devoted to mingsheng (名勝, "places of interest"). With such indiscriminate adoptions of the Ten Views model by other local patrons, the gap between real experiences and artistic depictions grew. This may be the reason for Lu Xun's withering criticism of the "ten views syndrome."

Though the practice of highlighting ten views was adopted by painters and poets to apply in other places, the Ten Views of West Lake continued to be a popular subject for painters, who tirelessly depicted the lake scenery with their brushes. Drawing on well-circulated visual and textual materials, painters could create new images without setting foot anywhere near the lake. Such images closely relied on the titles and the traditions associated with them, more than on the painters' emotional response to the place. As many locations mentioned in the Ten Views were destroyed or abandoned after the end of the Southern Song Dynasty, paintings based on the titles of these focal spots became increasingly disconnected from the real, ecologically altered natural scenes. Ironically then, while these ten titles were invented in response to an affective bond with the natural environment and were intended to evoke a positive attachment to the place, they also gradually could place personal connections with the nature in jeopardy. In addition to describing scenes that might no longer actually exist (at least in their original forms), the popularization of the visual and material cultural artifacts also made actual visits to the place optional. Thus, the Southern Song visual culture pertaining to West Lake

$61 \quad$ For example, the Eight Views of Ōmi 近江八景 were believed to be influenced by both the Eight Views of the Xiao and Xiang Rivers and the Ten Views of West Lake. For more discussion on the influence of West Lake on Japanese and Korean culture, see Jin, "Xihu zai Zhong Ri Han." 


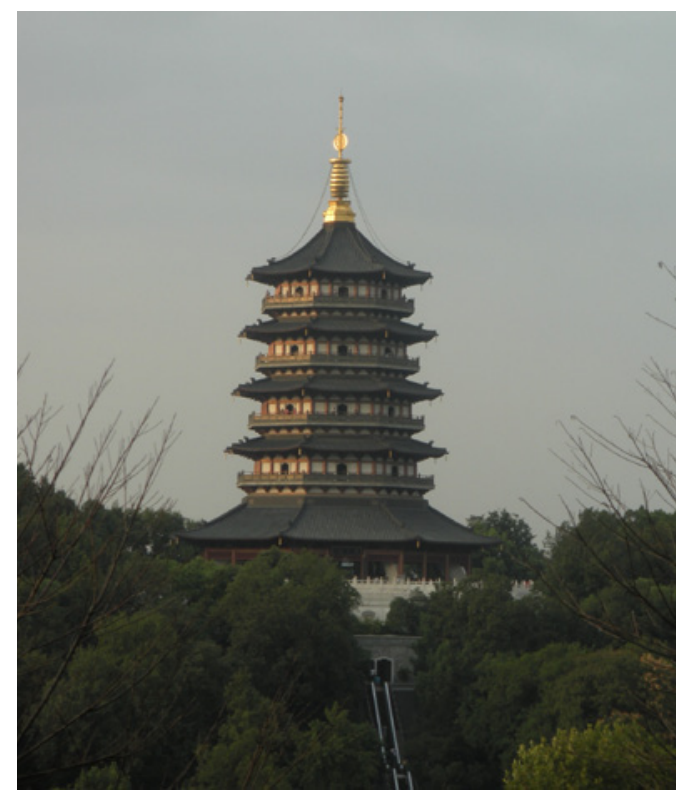

FIGURE 4.17

Today's Leifeng Pagoda (rebuilt in 2002), with elevator built in. Рното: XIAOLIN DUAN, 2011.

simultaneously framed and hindered later visitors' personal bonds with the environment.

In Hangzhou today, people are attempting to reconstruct the Ten Views by rebuilding the relevant sites, adding signposts to explain each view, and selling a variety of souvenirs. Lu Xun very likely would have disappointed to learn that Leifeng Pagoda was rebuilt (complete with an elevator, in 2002; see Figure 4.17) as a way to restore the Southern Song Ten Views and attract more visitors. Modern visitors, arriving almost eight hundred years after the inception of the Ten Views, can still find these places and images of them on tourist maps, encounter them while walking around the lake, capture the view of the Leifeng Pagoda against the sunset with their cameras, and purchase a group of ten postcards-each depicting one view like a modern ten-leaf album. Moreover, the local government has been inspired by the traditional Ten Views to organize citizens to vote for new versions of them. The visual culture of West Lake's Ten Views - popular through centuries of Chinese history - continues to provide a particular manner of describing and representing the landscape, encourages corresponding acts of viewing, and continues to enhance people's attachment to certain locations around the lake. 


\title{
References
}

\begin{abstract}
Abbreviations
SKQS Siku quanshu 四庫全書. Taipei: Taiwan shangwu yinshuguan, 1983-1986.

ZGSHQS Zhongguo shuhua quanshu zhencang ben 中國書畫全書 珍藏本. Lu Fusheng 盧輔圣, Cui Erping 崔爾平 and Jiang Hong 江宏 ed.. Shanghai: Shanghai shuhua chubanshe, 2000.
\end{abstract}

\section{Primary Sources}

Dongtian qinglu ji 洞天清錄集, by Zhao Xigu 趙希鵠 (fl. 1180-1240). Finished ca. 12251264. In Meishu congshu 美術叢書, edited by Huang Binhong 黃賓虹 and Deng Shi 鄧實. Taipei: Yiwen yinshu guan, 1960.

Fangyu shenglan 方輿勝覽, by Zhu Mu 祝穆 (fl. 13th century). Finished ca. 1225-1269. SKQS.

Fansheng lu 繁盛錄, by Xihu Laoren 西湖老人. Finished in 1250. Beijing: Wenhua yishu chubanshe, 1988.

Gugong shuhua tulu 故宮書畫圖錄, edited by Guoli gugong bowuyuan 國立故宮博物 院. Taipei: Guoli gugong bowuyuan, 1989.

Guhang zaji 古杭雜記, by Li You 李有. In Ding Bing 丁丙, Wulin zhanggu congbian 武 林掌故叢編. Taipei: Tailian guofeng chubanshe; Huawen shuju lianhe yinxing: Jinghua shuju, 1967.

Guixin zazhi 癸辛雜識, by Zhou Mi 周密 (1232-1298). Beijing: Zhonghua shuju: xinhua shudian Beijing faxingsuo faxing, 1988.

Haining xianzhi 海寧縣誌, by Jin Ao 金鏊 (fl. 18th century) et al. Published in 1765. Taipei: Chengwen chubanshe, 1983 .

Huaji 畫繼, by Deng Chun 鄧椿 (fl.1127-1167). Beijing: Renmin meishu chubanshe, 1963. Hua shanshui xu 畫山水序, by Zong Bing 宗炳 (375-443). Composed around 430. In Zhongguo hualun leibian 中國畫論類編, edited by Yu Jianhua 俞劍華. Beijing: Remin meishu chubanshe, 1986.

Huishi beikao 繪事備考, by Wang Yuxian 王毓賢 (fl. ca. 1691). SKQS.

Jiangcun xiaoxia lu 江村消夏錄, by Gao Shiqi 高士奇 (1645-1704). ZGSHQS.

Juemiao hao ci jian 絕妙好詞箋, by Zha Weiren 查為仁 (1694-1749), Li E 庽鶚. SKQS.

Mengliang lu 夢梁錄, by Wu Zimu 吳自牧(fl. ca. 1274). Finished ca. 1274. Beijing:Wenhua yishu chubanshe, 1988.

Mengxi bitan 夢溪筆談, by Shen Gua 沈括 (1031-1095). SKQS.

Nansongyuanhua lu 南宋院畫錄, by Li E 厲鶚 (1692-1752). Qiantang dingshi zhushutang, 1884.

Pinzhou yudi pu 蘋洲漁笛譜, Zhou Mi 周密 (1232-1298). SKQs.

Qinghe shuhua fang 清河書畫舫, by Zhang Chou 張丑 (1577-1643). ZGSHQS. 
Rihu yuchang 日湖漁唱, by Chen Yunping. In Congshu jicheng xinbian 叢書集成新編. Taipei: Xin wenfeng chuban gongsi, 1986.

Wulin jiushi 武林舊事, by Zhou Mi 周密 (1232-1298). Composed between 1280 and 1290. Beijing: Wenhua yishu chubanshe, 1988.

Xianchun Lin'an zhi 咸淳臨安志, by Qian Yueyou 潛說友 (fl. ca. 1268). Compiled in 1268. Song Yuanfangzhi congkan 宋元方志叢刊. Beijing: Zhonghua shuju:Xinhua shudian Beijing faxingsuo, 1990.

Xihuyoulan zhiyu 西湖遊覽志餘, by Tian Rucheng 田汝成(fl. 1526). Hangzhou: Zhejiang renmin chubanshe, 1980.

Xinjuan hainei qiguan 新鎸海內奇觀, by Yang Erzeng 楊爾曾 (fl. 17th century). Published in 1609. Shanghai: Shanghai guji chubanshe, 2002.

Yanshi shuhua ji 嚴氏書畫記, by Wen Jia 文嘉 (1501-1583). zGSHQS.

Yuxuan lidai shiyu 御選歷代詩餘, by Wang Yiqing 王奕清 (d.1736?), Shen Chenyuan 沈 辰垣 (fl. 17th-18th centuries), Xuanye 玄燁 (1654-1722). Finished in 1707. skQs.

\section{Secondary Sources}

Barnhart, Richard. "Shining Rivers: Eight Views of the Hsiao and Hsiang in Sung Painting." In International Colloquium on Chinese Art History: Proceedings, 45-95. Taipei: National Palace Museum, 1992.

Bol, Peter. "The Rise of Local History: History, Geography, and Culture in Southern Song and Yuan Wuzhou." Harvard Journal of Asiatic Studies 61.1 (Jun. 2001), 37-76. DOI:10.2307/3558587

Cahill, James. "The Imperial Painting Academy." In Possessing the Past: Treasures from the National Palace Museum, Taipei, 159-99. New York: Metropolitan Museum of Art, 1996.

Cahill, James. The Lyric Journey: Poetic Painting in China and Japan. Cambridge, Mass: Harvard University Press, 1961.

Chen Ye 陳野. Nansong huihua shi 南宋繪畫史. Shanghai: Shanghai guji chubanshe, 2008.

Clunas, Craig. Elegant Debts: The Social Art of Wen Zhengming, 1470-1559. Honolulu: University of Hawaii Press, 2004.

De Pee, Christian. "Nature's Capital: The City as Garden in The Splendid Scenery of the Capital (Ducheng jisheng, 1235)." In Senses of the City: Perceptions of Hangzhou and Southern Song China 1127-1179, edited by Christian de Pee, Joseph Lam, Shuen-fu Lin, and Martin Powers, 179-204. Hong Kong: The Chinese University Press, 2017.

Duan, Xiaolin. "A Comparative Study of Two Series of Printed West Lake Ten Views." In 2011 nian Beijing Daxue meishuxue boshisheng guoji xueshu luntan lunwenji 2011 年北 京大學美術學博士生國際學術論壇論文集, edited by Li Song 李松 and Ding Ning 丁 寧, 224-49. Xi'an: Shaanxi Normal University Press, 2012. 
Duan, Xiaolin. “Scenic Beauty outside the City: Tourism around Hangzhou's West Lake in the Southern Song (1127-1276)." PhD diss. University of Washington, 2014.

Egan, Ronald. "Nature and Higher Ideals in Texts on Calligraphy, Music, and Painting." In Chinese Aesthetics: The Ordering of Literature, the Arts, and the Universe in the Six Dynasties, edited by Zong-qi Cai, 277-309. Honolulu:University of Hawai'i Press, 2004.

Gernet, Jacques. Daily Life in China, On the Eve of the Mongol Invasion, 1250-1276. Stanford, Calif: Stanford University Press, 1962.

Harrist, E. Robert. Painting and Private Life in Eleventh-Century China. Princeton: Princeton University Press, 1998.

Harrist, E. Robert. "Site Names and Their Meaning in the Garden of Solitary Enjoyment." Journal of Garden History 13 (1993), 199-212. DOI:10.1080/01445170.1993.10412488

Huang, Amy. "Nature, Fengshui, and Political Symbolism: Pines on Mount Zhong during the Seventeenth Century." Presentation at the Annual Conference of Association for Asian Studies. March, 2016.

Huang, Shih-shan Susan. Picturing the True Form: Daoist Visual Culture in Traditional China. Cambridge, Mass.: Harvard University Asia Center, 2012.

Hymes, Robert P. "Marriage, Descent Groups, and the Localist Strategy in Sung and Yuan Fu-chou." In Kinship Organization in Late Imperial China, 1000-1940, edited by Patricia Buckley Ebrey and James L. Watson, 95-136. Berkeley and London: University of California Press, 1986.

I Lo-fen 衣若芬. “A New Exploration on Qing Palace's Collection of Ming Dynasty Artists Wang Fu's painting-“The Eight Views of Beijing” 玉堂天上: 清宮舊藏明代「北京八 景圖」新探. Gugong xuekan 16(2016), 283-96.

I Lo-fen. “'Landscape Like a Picture' and 'Landscape in the Picture': On the Song and Yuan Poems on the 'Xiaoxiang’ Landscape Paintings” 「江山如畫」與「畫裡江山」 : 宋元題「潚湘」山水畫詩之比較. Zhongguo wenzhe yanjiu jikan 23 (2003), 33-70.

Jin Wenjing 金文京. “Xihu zai Zhong Ri Han: Luetan fengjing zhuanyi zai Dong Ya wenxue zhong de yiyi." 西湖在中日韓——略談風景轉移在東亞文學中的意義. In Dong Ya wenhua yixiang zhi xingsu 東亞文化意象之形塑, edited by Shi Shouqian 石守謙 \& Liao Zhaoheng 廖肇亭, 141-66. Taipei: Yunchen wenhua shiye gufen youxian gongsi, 2001.

Lacan,Jacques. The Four Fundamental Concepts of Psycho-Analysis. London:Karnac, 2004. Lee, Hui-shu. Empresses, Art, and Agency in Song Dynasty China. Seattle: University of Washington Press, 2010.

Lee, Hui-shu. Exquisite Moments: West Lake \& Southern Song Art. New York: China Institute Gallery: Distributed by Art Media Resources, 2001.

Lee, Hui-shu. "The Domain of Empress Yang (1162-1233): Art, Gender and Politics at the Southern Song Court." PhD diss. Yale University, 1994.

Li Lincan 李霖橴. “Ye Xiaoyan de xihu tu ji qita” 葉肖䉷的西湖圖及其他. Gugongwenwu yuekan 28.7 (1985), 126-31. 
Lin Boting 林柏亭 et al. Daguan: Beisong shuhua tezhan 大觀：北宋書畫特展. Taipei: Guoli gugong bowuyuan, 2006.

Liu Fang 劉方. Shengshifanhua: Songdaijiangnan chengshi wenhua defanrongyu bianqian 盛世繁華: 宋代江南城市文化的繁榮與變遷. Hangzhou: Zhejiang daxue chubanshe, 2011.

Liu, Lihong. "Collecting the Here and Now: Birthday Albums and the Aesthetics of Association in Mid-Ming China." Journal of Chinese Literature and Culture. 2.1 (2015), 43-91. DOI:10.1215/23290048-2887553

Liu, T.C. James. China Turning Inward: Intellectual-Political Changes in the Early Twelfth Century. Cambridge, Mass.: Harvard University Press, 1988.

Loehr, Max. The Great Painters of China. New York: Harper \& Row, 1980.

Lu, Xun, Xianyi Yang, and Gladys Yang. Selected Works of Lu Hsun. Beijing: Foreign Languages Press, 1956.

Mitchell, W. J. T. Iconology: Image, Text, Ideology. Chicago: University of Chicago Press. 1986.

Miyazaki, Noriko 宮崎法子. “Saiko o meguru kaiga” 西湖をめぐる絵画. In Chūgokukinsei no toshi to bunka 中國近世の都市と文化, edited by Kaoru Umehara 梅原郁, 199246. Kyōto-shi: Kyōto Daigaku Jinbun Kagaku Kenkyūjo, 1984.

Murck, Alfreda. "Eight Views of the Hsiao and Hsiang Rivers by Wang Hong." In Images of the Mind, edited by Wen C. Fong, 214-35. Princeton: The Art Museum, Princeton University, 1984 .

Murck, Alfreda. Poetry and Painting in Song China: the Subtle Art of Dissent. Cambridge. Mass: Harvard University Asia Center for the Harvard-Yenching Institute, 2000.

Ortiz, Valérie Malenfer. Dreaming the Southern Song Landscape: the Power of Illusion in Chinese Painting. Boston: Brill, 1999.

Powers, Martin. "Picturing time in Song Painting and Poetry." In Senses of the City: Perceptions of Hangzhou and Southern Song China 1127-1179, edited by Christian de Pee, Joseph Lam, Shuen-fu Lin and Martin Powers, 55-72. Hong Kong: Chinese University Press, 2017.

Shi Shouqian 石守谦. Yidong de taohua yuan: Dong Ya shijie zhong de shanshui hua 移 動的桃花源：東亞世界中的山水畫. Beijing: Shenghuo, dushu, xinzhilian shudian, 2015 .

Tuan, Yi-fu. Topophilia: A Study of Environmental Perception, Attitudes, and Values. Englewood Cliffs, N.J.: Prentice-Hall, 1974.

Urry, John and Larsen Jonas. The Tourist Gaze 3.o. London: Sage Publications, 2011.

Wang, Y. Eugene. "Tope and Topos: The Leifeng Pagoda and the Discourse of the Demonic." In Writing and Materiality in China: Essays in Honor of Patrick Hanan, edited by Patrick Hanan, Judith T. Zeitlin, Lydia He Liu, and Ellen Widmer, 488-552. Cambridge, Mass.: Harvard University Asia Center, 2003. 
West, Stephen. "The Interpretation of a Dream: The Sources, Evaluation, and Influence of the Dongjing meng hua lu." T'oung Pao 71.1/3 (1985), 63-108. Dor: 10.1163/ 156853285 Xooo34

Wu Gangyi 吳剛毅. “Lu Hong ji qi huaji wei e yuanliu kaojian” 盧鴻及其畫跡偽訛源流 考 鑑. M.A. Thesis, Taiwan shifan daxue meishu xi, 1998.

Zhuang Shen 莊申. Tang Lu Hong caotang shizhi tu juan kao 唐盧鴻草堂十志圖卷考. Taipei: Zhongyang yanjiuyuan lishi yuyan yanjiusuo, 1960. 